\title{
DOSSIÊ
}

Sociologias, Porto Alegre, ano 4, no 8, jul/dez 2002, p. 84-135

\section{Exclusão socioeconômica e violência urbana ${ }^{1}$}

SÉRGIO ADORNO*

\section{O contexto mais amplo}

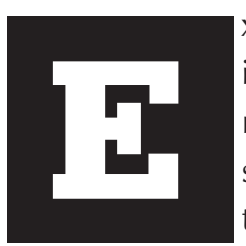

x-colônia portuguesa, a sociedade brasileira conquistou sua independência nacional em 1822 sob um regime monárquico. Suas bases socioeconômicas e políticas repousavam na grande propriedade rural, monocultora e exportadora de produtos primários para o mercado externo; na exploração extensiva de força de trabalho escrava, alimentada pelo tráfico internacional de negros desenraizados de suas tribos e comunidades de origem no continente africano; na organização social estamental (Weber, 1971; Fernandes, 1974) que estabelecia rígidas fronteiras hierárquicas entre brancos, herdeiros do colonizador português, negros escravizados, homens livres destituídos da propriedade da terra e populações indígenas. Esses fundamentos sociais conformaram uma vida associativa - isto é, padrões de socialidade e de sociabilidade - constituída em torno do parentesco, da mescla de interesses materiais e morais, da indiferenciação entre as fronteiras dos negócios públicos e dos interesses privados, no adensamento da vida íntima, na intensidade dos vínculos emocionais, no elevado grau de intimidade e de proximidade pessoais e na perspectiva de sua continuidade no tempo e no espaço, sem precedentes (Adorno, 1988, p. 28). 
Por sua vez, o poder político encontrava seus fundamentos institucionais no patrimonialismo, isto é, uma estrutura de dominação cuja legitimidade esteve assentada nas relações entre grandes proprietários rurais, representantes do estamento burocrático e clientelas locais às quais se distribuíam prebendas em troca de favores ou de apoio político. Vale dizer, um estilo próprio de regimes políticos oligárquicos com escassa organização político-partidária e frágil mobilização dos grupos subalternos. Neste contexto, a política convertia-se em "conversa entre cavalheiros" e os partidos, em colegiados de oligarcas (O’Donnell, 1988).

Essa estrutura perdurou ao longo de seis décadas (1822-1889). Contribuiu para consolidar elites políticas regionais. Ao longo da segunda metade do século XIX, profundas transformações, provocadas pela intensa produção de café para o mercado exportador, produziram fendas neste edifício social e político. Seus principais resultados residiram em: a) transferência definitiva do eixo econômico da região Nordeste, cujas atividades produtivas se concentravam na monocultora agro-exportadora do açúcar, para a região Sudeste, em especial para o oeste da província de São Paulo; b) substituição da força de trabalho escrava pela força de trabalho livre (1888), sobretudo constituída de imigrantes europeus contratados, inicialmente para as lavouras sob regime de colonato (Martins, 1971) e, em seguida, incorporados às oficinas e indústrias recém-instaladas, em torno de 1870, na capital da província de São Paulo; c) substituição do regime monárquico pelo de República Federativa (1889).

A história que se segue radicaliza este conjunto de processos sociais. Entre 1880 e 1930, a sociedade brasileira abandona progressivamente seu perfil agrário-exportador e ingressa na era da indústria e do trabalho livre e da maior dependência da política econômica face à dinâmica do mercado externo e do comércio cada vez mais internacionalizado. Desde os primeiros anos de vida republicana, as tendências sociais caminharam no sentido da substituição progressiva das relações hierárquicas estamentais pela 
moderna formação da moderna sociedade de classes, com a constituição de um vigoroso e combativo proletariado urbano, em particular nas cidades de São Paulo, Rio de Janeiro e na portuária cidade de Santos, situada na mesma região Sudeste. Aprofundaram-se as desigualdades regionais e a concentração da riqueza sob controle dos cafeicultores, dos proprietários rurais e da nova classe de empresários industriais. A polarização social agravou-se, estimulando revoltas no campo e uma onda de greves nas cidades industriais.

Em torno da segunda metade do século XX, desenvolveu-se, no Estado de São Paulo, complexo parque industrial, em grande parte estimulado pela substituição de exportações ocorrida durante a II Grande Guerra, pela política de subsídios estatais, por forte regulação das atividades econômicas e acentuado protecionismo da indústria nacional. Esta tendência contribuiu para aprofundar o capitalismo na sociedade brasileira, para o elevado crescimento econômico, em especial na década de 1970, e para a modernização da infra-estrutura tecnológica, da infra-estrutura urbana e para a emergência de amplas massas sociais no cenário político. Ao longo desse período é acelerado o associativismo, sob a forma de sindicatos e organizações profissionais. Cresce também o eleitorado, em particular urbano, em proporções muito superiores às da população como um todo (Santos, 1993). A violenta crise socioeconômica que se abateu sobre a sociedade brasileira na década de 1980 - a chamada década perdida - e primeiros anos da década de 1990, com suas elevadas taxas de inflação e baixo crescimento, mostraram que o modelo de substituição das exportações se havia esgotado. Os governos civis (1989 até o presente), eleitos por sufrágio universal, buscaram então saídas na abertura da economia, em amplo programa de privatizações, na integração da economia brasileira ao mercado globalizado.

Nas duas últimas décadas, novas tendências de crescimento econômico e desenvolvimento social mudaram profundamente o perfil e a dinâ- 
mica desta sociedade. Foram modernizados importantes segmentos do mercado; ampliou-se o parque industrial e tecnológico; verificaram-se avanços na direção de serviços altamente informatizados; a despeito das enormes carências sociais e da dívida social acumulada, houve progressos nos domínios da escolarização fundamental e mesmo da saúde pública (conquanto a recente epidemia de dengue coloque sob suspeita os ganhos alcançados). Atravessou-se grave crise política que resultou no impeachment do presidente Collor de Mello (1989-1992), sem que a normalidade constitucional e a ordem democrática fossem interrompidas, como ocorrera em passado não muito distante. Avanços democráticos também puderam ser notados em não poucos domínios: maior transparência das decisões governamentais, maior liberdade de imprensa, maior liberdade de circulação de idéias e de associação, maior interesse dos cidadãos em questões públicas que se dizem diretamente respeito, como consumo e meio ambiente, maior atuação de órgãos de vigilância das ações governamentais, como o Ministério Público e ouvidorias. Aqui e acolá, governos democráticos buscaram enfim exercer o princípio republicano da responsabilidade pública e política. Ao mesmo tempo, a sociedade brasileira tornou-se mais densa e mais complexa nas suas relações de classe, nas suas relações intersubjetivas, nas lutas sociais pelo reconhecimento de identidades e de direitos; mais reivindicativa, mais participativa, cada vez mais inconformada com a persistência de seus problemas, entre os quais a violência urbana cotidiana.

Não obstante, os padrões de concentração de riqueza e de desigualdade social permaneceram os mesmos de quatro décadas. A desigualdade de direitos e de acesso à justiça agravou-se na proporção mesma em que a sociedade se tornou mais densa e mais complexa. Os conflitos sociais tornaram-se mais acentuados. Neste contexto, a sociedade brasileira vem conhecendo crescimento das taxas de violência nas suas mais distintas modalidades: crime comum, violência fatal conectada com o crime orga- 
nizado, graves violações de direitos humanos, explosão de conflitos nas relações pessoais e intersubjetivas. Em especial, a emergência do narcotráfico, promovendo a desorganização das formas tradicionais de socialidade entre as classes populares urbanas, estimulando o medo das classes médias e altas e enfraquecendo a capacidade do poder público em aplicar lei e ordem, tem grande parte de sua responsabilidade na construção do cenário de insegurança coletiva ${ }^{2}$.

\section{O cenário da violência urbana}

A sociedade brasileira, egressa do regime autoritário, há duas décadas, vem experimentando, pelo menos, quatro tendências: a) o crescimento da delinqüência urbana, em especial dos crimes contra o patrimônio (roubo, extorsão mediante seqüestro) e de homicídios dolosos (voluntários); b) a emergência da criminalidade organizada, em particular em torno do tráfico internacional de drogas, que modifica os modelos e perfis convencionais da delinqüência urbana e propõe problemas novos para o direito penal e para o funcionamento da justiça criminal; c) graves violações de direitos humanos que comprometem a consolidação da ordem política democrática; d) a explosão de conflitos nas relações intersubjetivas, mais propriamente conflitos de vizinhança que tendem a convergir para desfechos fatais ${ }^{3}$. Trata-se de tendências que, conquanto relacionadas entre si, radicam em causas não necessariamente idênticas.

\footnotetext{
de 2002. Nesta versão, introduzi modificações.

*Departamento de Sociologia, FFLCH/USP. Núcleo de Estudos da Violência/USP. E-mail: sadorno@usp.br.

2 Para uma visão mais detalhada da história social e política da sociedade brasileira, ver Lamounier (1999).

3 Aqui é necessário fazer uma explicação de ordem conceitual. Crime é um conceito jurídico. Diz respeito à violência codificada nas leis penais. Sabe-se, porém, que nem todo fenômeno socialmente percebido como violento é categorizado como crime. Do mesmo modo, há modalidades de violência que, embora codificadas como crime, não encontram adequado enquadramento na legislação penal correspondente. Por exemplo, graves violações de direitos humanos não raro enquadradas como crime comum. Por isso, recorro ao conceito sociológico de violência. Segundo Zaluar (1999), "violência vem do latim violentia que remete a vis (força, vigor, emprego de força física ou os recursos do corpo para exercer sua força vital). Essa força torna-se violência quando ultrapassa um limite ou perturba acordos tácitos e regras que ordenam relações, adquirindo carga negativa ou
} 
Embora o crescimento da criminalidade urbana seja matéria controvertida, as estatísticas oficiais de criminalidade ${ }^{4}$, base sobre a qual se realizam diagnósticos, avaliações, análises e estudos científicos estão apontando no sentido de uma tendência mundial, desde os anos 50, para o crescimento dos crimes e da violência social e interpessoal, ainda que as taxas indiquem sensíveis declínios no curso da década de 1990, sobretudo nos Estados Unidos, ao que parece estimuladas em parte pelo desenvolvimento econômico, pela redução do desemprego, pela expansão do mercado consumidor e do bem-estar, ao lado certamente dos efeitos provocados por inovadoras políticas de segurança ${ }^{5}$.

Não era de esperar que a sociedade brasileira estivesse imune a este movimento de tendências crescentes, sobretudo porque o país se encontra no circuito das rotas do tráfico internacional de drogas e de outras modalidades de crime organizado em bases transnacionais como o contrabando de armas, atividades que parecem constituir-se na bomba de combustão do crescimento da criminalidade violenta. Mais surpreendente, contudo, é verificar que as taxas de criminalidade violenta no Brasil em cidades como Rio de Janeiro e São Paulo, são superiores inclusive às taxas de algumas metrópoles norte-americanas.

Não há dados nacionais sobre delinqüência, crime e violência urbana. Os únicos dados nacionais disponíveis alcançam os homicídios. Porém não estão baseados em registros policiais. Dizem respeito à mortalidade por causas externas, dado extraído dos registros oficiais de óbito, cujo armazenamento é de responsabilidade do Ministério da Saúde. Com base nessas informações, observa-se que os homicídios evoluíram de 21,04/

\footnotetext{
maléfica. É portanto a percepção do limite e da perturbação (e do sofrimento que provoca) que vai caracterizar o ato como violento, percepção essa que varia cultural e historicamente" (Zaluar, 28).

4 As estatísticas oficiais de criminalidade comportam não poucos problemas, entre os quais a suspeição de elevadas "cifras negras", a intervenção de critérios burocráticos de avaliação de desempenho administrativo, as "negociações" paralelas entre vítimas, agressores e autoridades, a implementação de políticas determinadas de segurança pública que conjunturalmente privilegiam a contenção de uma ou outra modalidade delituosa e ainda a desistência da vítima em denunciar ocorrência motivada por desinteresse pessoal ou descrença na eficácia das instituições. A respeito, ver: Paixão (1983), Coelho (1988), Fundação João Pinheiro (1986), Robert et al. (1994), Wright (1987).

5 Para o caso inglês, ver sobretudo Moris, 1989; Maguire. 1997; para a França, Robert et al., 1994; quanto os Estados Unidos,
} 
100000 habitantes, em 1991, para 25,33/100000, em 1997. Para melhor compreender essas taxas, convém reportar-se aos dados internacionais para o ano de 1995: enquanto, no Brasil, a taxa alcançou 23,83/100000 habitantes, nos Estados Unidos acusou 8,22; na Grã-Bretanha, 2,43; na Itália, 4,90; na Bélgica, 4,11; em Portugal, 3,99; na França, 4,11 (Brasil, Datasus, Ministério da Saúde, 1995; França, Ministério do Interior, 1997; USA, Union Crime Reports, 1996). Camargo \& outros (1995) observam que, no Brasil, ao longo da década de 1980, enquanto o número total de óbitos cresceu $20 \%$, os óbitos motivados por causas violentas cresceram $60 \%$.

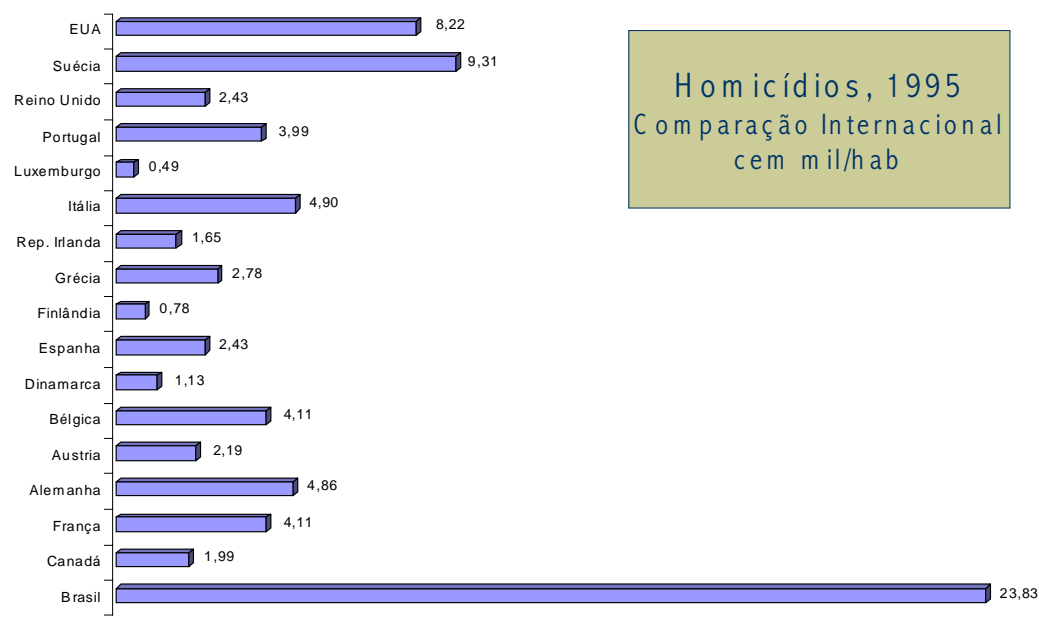

Sources: Brasil - Datasus; Europe - État de la Criminalité et la Délinquance en France et dans l'Union Europeenne Ministere de L'Interieur; USA - Uniform Crime Reports, 1996, U.S. Dept. of Justice, FBI; Canada - Statcan.ca

\section{Gráfico 1}

Donziger, ed. 1996; Garland, 2001; Kelling \& Coles, 1996; Skogan, 1997.

6 Há controvérsia sobre a comparabilidade entre os dados para o período de 1991-95 e 1996-97, uma vez que, a partir de 1996, 
Tabela 1. Distribuição das ocorrências policiais que envolvam adolescentes infratores segundo número de pessoas envolvidas - Município de São Paulo-1988-91 e 1993-96(1)

\begin{tabular}{lcc} 
Número de pessoas envolvidas & \multicolumn{2}{c}{$\begin{array}{c}\text { Distribuição das } \\
\text { ocorrências policiais }\end{array}$} \\
\multicolumn{1}{c}{ Total } & 100,0 & 100,0 \\
Ação isolada & 43,0 & 30,5 \\
Ação em conjunto com um ou mais adolescente & 38,0 & 44,8 \\
Ação em conjunto com um ou mais adulto & 11,5 & 22,3 \\
Ação em conjunto com outros envolvidos não identificados & 7,5 & 2,4
\end{tabular}

Fonte: Poder Judiciário/Varas Especiais da Infância e da Juventude da Capital; Convênio Fundação Sistema Estadual de Análise de Dados - Seade/Núcleo de Estudos da Violência - NEV/USP.

(1) Refere-se ao número total de passagens dos adolescentes infratores pelo Sistema Judiciário, nos períodos.

Nem todas as mortes registradas no Brasil, no período considerado, estão relacionadas com a delinqüência e o crime urbanos, segundo a classificação anteriormente referida. Compreendem também desfechos fatais resultantes de disputas no domínio do narcotráfico, resultantes de graves violações de direitos humanos (como mortes praticadas por agentes policiais em situação de abuso de uso da força física, mortes praticadas por justiceiros e grupos de extermínio, mortes em linchamentos), bem como resultantes de conflitos nas relações intersubjetivas.

Recente estudo sobre as tendências do homicídio, para o país em seu conjunto, constatou que: a) o número de homicídios causados por armas de fogo vem crescendo desde 1979; b) esse número cresceu mais rapidamente do que o crescimento da população. Em Brasília (Distrito Federal), em 1980, a taxa de homicídios era de 13,7 por cem mil habitantes; em 1991, isto é, onze anos depois, saltou para 36,3 (Dillon Soares, 2000). Em algumas capitais brasileiras, as taxas encontram-se, no ano de 1997, muito acima da média nacional: Recife, capital do Estado de Pernambuco (105,3/ 100000 hab,); Vitória, capital do Estado do Espírito Santo (103,40/100000 hab.); Rio de Janeiro, capital do Estado do Rio de Janeiro (65,79/100000 
hab.); São Paulo, capital do Estado de São Paulo (56,69/100000 hab.). Em torno de $21 \%$ de todos os homicídios registrados, no Brasil, no ano de 1998, concentraram-se apenas em duas capitais brasileiras, as duas mais populosas do país: Rio de Janeiro e São Paulo. As respectivas regiões metropolitanas seguem padrão idêntico. Enquanto a taxa de homicídio cresceu 209\% no Brasil, no período de 1980 a 1998, nas doze regiões metropolitanas cresceu $262,8 \%$. Nessas regiões, vivia, em 1998, 36,7\% da população brasileira. No mesmo ano, respondeu por $57,7 \%$ do total de mortes resultantes de homicídios voluntários ou agressões (cf. Mesquita Neto, 2001).

Em todo o país, o alvo preferencial dessas mortes compreende adolescentes e jovens adultos masculinos, em especial procedentes das chamadas classes populares urbanas, tendência que vem sendo observada em inúmeros estudos sobre mortalidade por causas violentas (Mello Jorge, 1981, 1982 e 1986; Soares e outros, 1996; Yazabi \& Ortiz Flores, 1988; Zaluar, 1994; Assis, 1997; Saad e outros, 1998). No município de São Paulo, no período de 35 anos (1960-1995), o coeficiente de homicídios para adolescentes, do sexo masculino, na faixa de 15-19 anos, passou de 9,6 para $186,7 / 100000$ habitantes, vale dizer um crescimento da ordem de $1800 \%$ (Mello Jorge, 1998). Pesquisa realizada no início da década passada estimou em 2.7/dia o número de jovens assassinados no Estado de São Paulo, no ano de 1990. Este mesmo estudo revelou que a grande maioria das vítimas havia sido morta mediante emprego de arma de fogo, circunstância indicativa da intencionalidade na consumação da morte (Castro, 1993) ${ }^{7}$.

O gráfico 2, a seguir, ilustra esta tendência.

o banco de informações - DATASUS - modificou a classificação anteriormente utilizada. Cf. DATASUS, Ministério da Saúde, Governo Federal, Brasil.

7 A pesquisa, realizada mediante apoio do Centro Brasileiro para a Infância e Adolescência (FCBIA), escritório de São Paulo, 


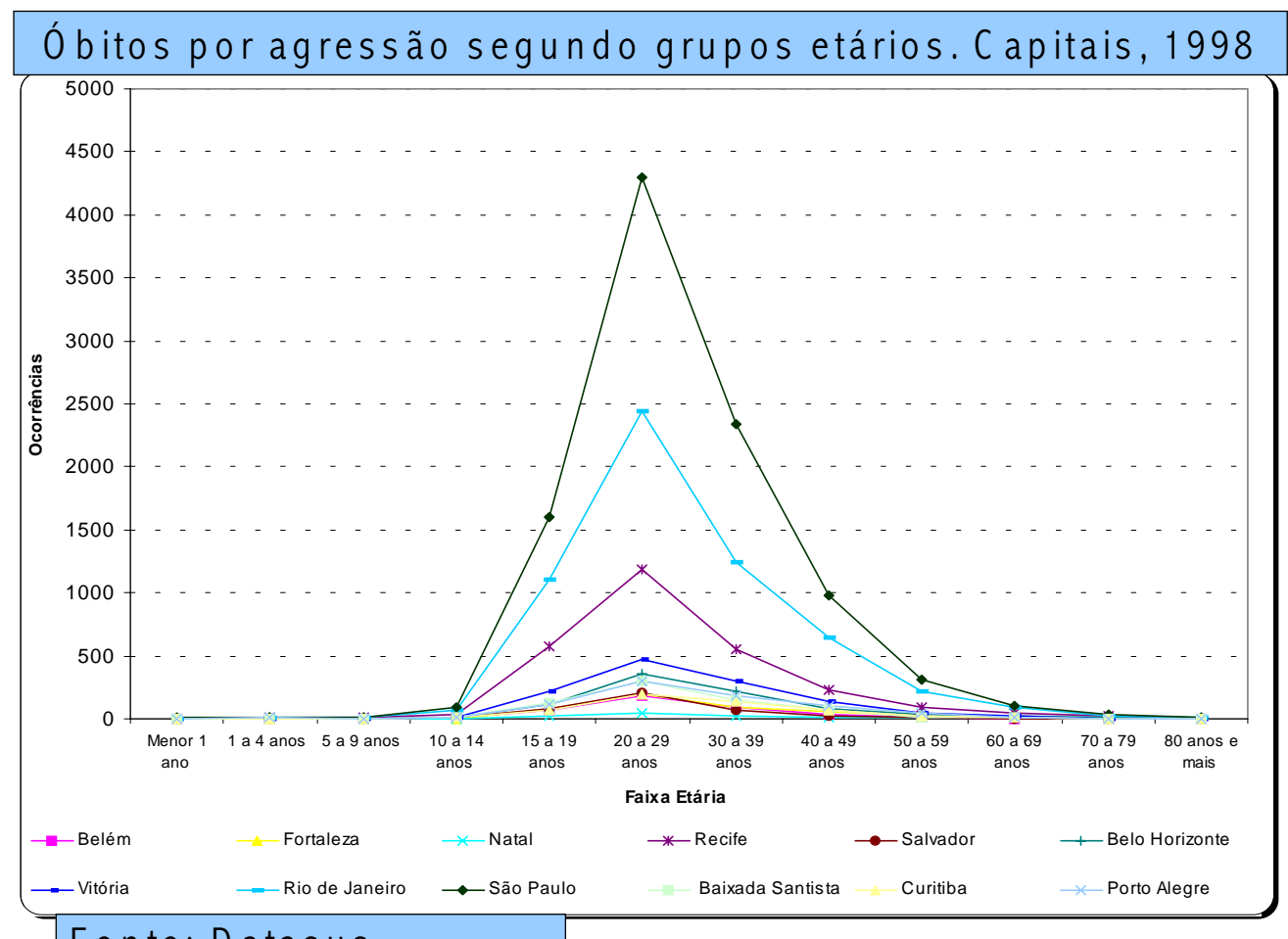

Gráfico 2 
Mas os jovens também comparecem como autores da violência. Estudo realizado para o Município de São Paulo, entre os anos de 1989-1991 e 1993-1996, observando comportamento infracional de adolescentes de 1218 anos incompletos, identificou algumas tendências semelhantes. O perfil dos adolescentes que se envolvem com atos infracionais não é distinto do perfil da criminalidade na população adulta. Ao contrário do que indicam expectativas no interior da opinião pública, é baixa a proporção de jovens que cometem homicídios. Representou, no segundo período, 1,3\% de todas as infrações cometidas. Comparando-se ambos períodos, não houve crescimento estatisticamente significativo nas distintas modalidades infracionais. Porém foram observadas, pelo menos, duas importantes mudanças. Aumentou a proporção de adolescentes representados na criminalidade violenta. No primeiro período, era menor a proporção de crimes violentos cometidos pelos adolescentes face à proporção de crimes violentos cometidos na população em geral. No segundo período, esta tendência se inverte. Os adolescentes também revelam-se mais comprometidos com a prática de atos infracionais em bandos ou quadrilhas (Adorno, Lima e Bordini, 1999).

Fortes tendências também podem ser observadas, em várias capitais brasileiras e respectivas regiões metropolitanas, quanto ao crescimento do conjunto de crimes violentos ${ }^{8}$. Não há dados nacionais a respeito. Os dados disponíveis são estaduais, a fonte originária compreende registros de ocorrências policiais. A título de ilustração, no Município de São Paulo, entre 1984 e 1993, a participação dos crimes violentos no total da massa de crimes registrados cresceu 10,1\% (Feiguin \& Lima, 1995). Este mesmo estudo aponta que o crescimento foi mais acelerado a partir de 1988, quando esta

contou com a coordenação de Myriam Mesquita Pugliese de Castro e a participação dos pesquisadores Cristina Eiko Sakai, Amarylis Nóbrega Ferreira, Nelson A. Casagrande e Marcelo Gomes Justo.

8 No Brasil, as infrações previstas no Código Penal, classificam-se em contravenção (infrações de menor gravidade) e crime (infrações de maior gravidade). Nesta última categoria, recente legislação penal promoveu distinção entre crimes e crimes hediondos. Estes últimos alcançam crimes como extorsão mediante seqüestro, estupro e homicídios conectados com o tráfico internacional de drogas. Em termos sociológicos, distinguem-se crimes violentos (aqueles que representam ameaça à integridade física ou à vida de quem quer que seja) dos crimes não violentos. Entre os crimes violentos, comparecem homicídios 
modalidade de delinqüência passou a representar, em média 28,8\% do total das ocorrências registradas. Para o período posterior a 1988, Feiguin \& Lima atestaram a retomada do crescimento dessas taxas: "... nota-se que os crimes violentos saltaram de uma taxa de 945,1 por 100.000 habitantes, em 1988, para 1.119,2 por 100.000 habitantes, em 1993. Trata-se de um crescimento da ordem de 18,4\% num período de seis anos..." (p. 76).

Além dos homicídios já mencionados, pesam os crimes violentos contra o patrimônio, em especial roubos ${ }^{9}$. Entre 1991 e 1996, foi mais elevada a taxa de crescimento dos roubos que dos furtos, na região metropolitana de São Paulo. Essa taxa foi ainda mais elevada nos bairros que compõem a periferia comparativamente às áreas centrais dessa região (Caldeira, 2000) . Estudos indicam que é o crime violento, sobretudo o crescimento dos homicídios, que parece estar na raiz dos sentimentos de medo e insegurança da população urbana (Cardia, 1999). É bem provável que o aumento desses crimes, notadamente dos homicídios voluntários, responda à emergência do crime organizado no Brasil, como aliás sustenta Zaluar em inúmeros estudos (1994, 1998, 2000).

No domínio dos direitos humanos, o cenário da violência não é menos significativo. Persistiram as mortes causadas por policiais militares ${ }^{10}$ em confronto com civis. Já na década de 1980, pesquisa realizada pelo Núcleo de Estudos da Violência da USP (Pinheiro et al., 1991), relativa ao período de 1983 a 1987, concluiu que

voluntários, roubos, roubos seguido de morte (latrocínio) extorsão mediante seqüestro, estupro.

9 Há que se fazer uma distinção entre roubo e furto. Na legislação penal brasileira, ambos compreendem crime contra o patrimônio. Porém, o roubo é a subtração de propriedade alheia mediante grave ameaça à integridade física ou à vida de quem quer que seja. Trata-se de um crime violento. Por sua vez, o furto é também subtração de propriedade alheia, contudo sem o recurso à violência. Trata-se, por conseguinte, de crime não violento.

10 No Brasil, o policiamento preventivo e repressivo compete à Polícia Militar. As tarefas de polícia judiciária, isto é, de realização das investigações visando o reconhecimento da materialidade do delito e identificação de possível ou possíveis autores competem à Polícia Civil. Ambas, Polícia Militar e Polícia Civil, pertencem à esfera dos governos estaduais. Como se sugeriu anteriormente, todo registro policial deveria, em princípio, ensejar a abertura de inquérito policial. Uma vez aberto e concluído, o inquérito policial é encaminhado ao poder Judiciário e distribuído ao juiz. Este, por sua vez, encaminha-o ao Ministério Público - órgão que possui independência face ao Executivo e ao Judiciário. No MP, o inquérito será apreciado pelo promotor público, que poderá solicitar novas investigações policiais, o arquivamento do inquérito por insuficiência de provas ou apresentar denúncia. Caso a denúncia seja aceita pelo juiz, instaura-se o processo para apuração de responsabilidade penal, oportunidade em que o indiciado no inquérito policial se transforma em réu perante à Justiça penal. Salvo nos casos 
mais de 3.900 pessoas (foram) mortas, entre policiais e não-policiais, e mais de 5.500 feridos, dados apenas da Polícia Militar. O número de mortos chega à média de 1,2 morte por dia no período, com a máxima de 1,6 em 1985. [...] Os totais de mortes em confronto com a polícia no Estado de São Paulo são extremamente altos, tendo também em vista outros países. Como comparação, na Austrália, que possui uma população de cerca de 17 milhões de habitantes, pouco menos que a da região da Grande São Paulo, de 1974 a 1988 foram mortas 49 pessoas e 21 policiais, ou seja, 46 vezes menos $^{11}$.

Na década seguinte, não foi diferente. No ano de 1992, a Polícia Militar atingiu seu ápice, abatendo 1.470 pessoas, valor que inclui 111 mortos no massacre da Casa de Detenção, em São Paulo ${ }^{12}$.

Embora não se possam fazer generalizações ${ }^{13}$, esta escalada da violência policial pôde ser observada em outros Estados da federação, em especial no Rio de Janeiro, onde são freqüentes as incursões policiais nos morros, favelas e áreas de concentração de habitações populares com o propósito de prender traficantes ou conter o tráfico de drogas. Não raro, essas incursões resultam em mortes de delinqüentes, em confronto com a polícia e são justificadas em nome de resistência à ordem de prisão. Mas há também, entre as vítimas, moradores ou transeuntes não envolvidos em atividades criminosas ou sob suspeita de estarem envolvidas $^{14}$ (NEV-USP, 1993; Cano, 1998). Embora esta modalidade de violência policial tenha oscilado a partir de 1993, ela foi constante e voltou novamente

\footnotetext{
de homicídios dolosos, o processo de apuração da responsabilidade penal segue, em linhas gerais, essa trajetória. Em conseqüência, o conjunto de agências que intervêm nesse processo compreende o que se costuma chamar de sistema de justiça criminal. Quanto aos crimes de competência da União, eles ficam a cargo da Polícia Federal, subordinada ao Ministério da Justiça e sob a jurisdição dos tribunais federais.

11 Instigante estudo comparativo entre Jamaica, Argentina e Brasil a respeito das mortes cometidas pelas forças policiais encontra-se em Chevigny (1990).

12 V. Amaral, L. H. Fleury [governador do Estado de São Paulo] diz que massacre fez PM mudar. Folha de S. Paulo. São Paulo, 29/03/1993. Caderno 1-9. Sobre o mesmo assunto, veja-se também Barcellos (1993) e Caldeira (2000).

13 Não se pode fazê-las porque o maior ou menor envolvimento de policiais militares nesses episódios depende não apenas das características locais da organização, bem como da maior ou menor ascendência do Executivo estadual sobre suas
} 
a crescer no curso de 1998, conforme apontam registros oficiais e especialmente os relatórios da Ouvidoria da Polícia (www.ouvidoria-policia.sp.gov.br), instituto criado pelo governo do Estado de São Paulo, em 1996, justamente para o monitoramento destes casos, modelo que outros governos estaduais perfilharam, como os Estados do Rio de Janeiro e Pará.

Graves violações de direitos humanos praticadas por policiais não se encontram desacompanhadas neste ciclo, ao que parece crescente, de violência ilegal e de vinganças privadas. Verificou-se, no curso das duas últimas décadas, verdadeira explosão de litigiosidade no seio da sociedade civil, em particular nos bairros onde habitam majoritariamente classes trabalhadoras de baixa renda, resultando em desfechos fatais. Em particular, parecem terse intensificado casos de linchamentos e execuções sumárias praticados por grupos de extermínio, de esquadrões da morte, bem como de chacinas.

Neste cenário, convém ainda ressaltar a veiculação, através da mídia impressa e eletrônica, de casos de linchamento ${ }^{15}$, há pelo menos duas décadas. Embora não se trate de fenômeno recente - a historiografia registra inclusive a ocorrência de casos desta espécie desde a Colônia (15001822) - eles parecem ter-se intensificado nas duas últimas décadas, em particular em cidades como São Paulo e Salvador (Pinheiro, Adorno, Cardia e col., 1999) ${ }^{16}$. Os estudos disponíveis sugerem que tais conflitos tendem a ocorrer em contextos de profundas rupturas nas hierarquias sociais tradicionais, impulsionadas pelo crescimento do crime violento e seu impacto sobre as formas de socialidade e sociabilidade anteriormente dominantes, sobretudo em bairros que compõem a periferia de grandes regiões metropolitanas como a de São Paulo. Ao que tudo indica, essas rupturas afetam

\footnotetext{
organizações policiais.

14 As razões para explicar este padrão de atuação são históricas, remontam ao modo pelo qual, no processo de construção da sociedade e do Estado nacionais, se articularam o poder judicial e o poder político local, de forma que o Estado jamais logrou completo controle do monopólio estatal da violência. Nos limites deste artigo, não é possível explorar melhor esse quadro histórico, embora fosse desejável fazê-lo. Para uma análise recente, ver Caldeira (2000).

15 Grosso modo, linchamentos consistem em atos de vingança coletiva e de aplicação de justiça privada, praticados em momento de explosão emocional, contra alguém que tenha sido identificado, em um bairro determinado, como responsável por crimes ou pela ocorrência de um grave crime, como estupro, por exemplo. Freqüentemente a vítima é levada a espaço
} 


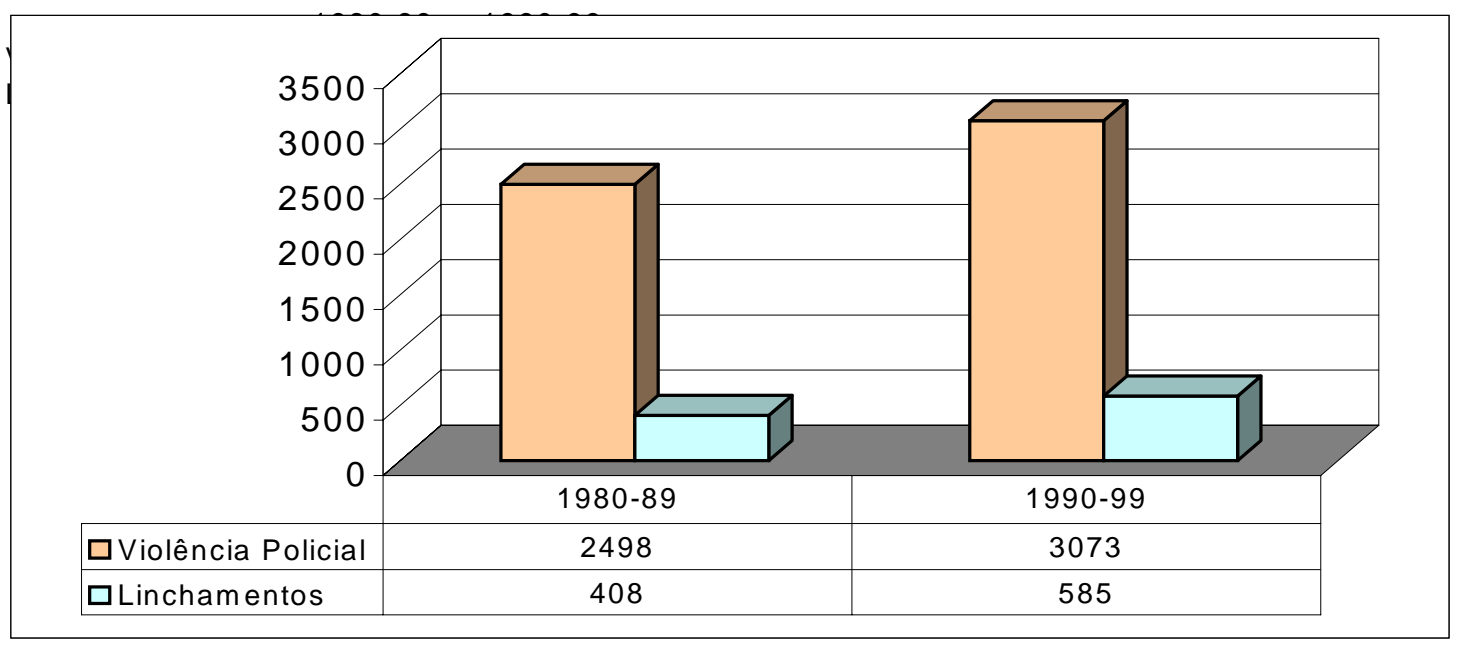

Fonte: Banco de Dados da Imprensa Sobre as Graves Violações de Direitos Humanos NEV/USP - FORD/FAPESP/CNPq

Secretaria de Estado de Direitos Humanos/Ministério da Justiça

Gráfico 3. Total de casos de linchamento e violência policial - Brasil, 1980-1999 
justamente as hierarquias que estruturam e organizam as relações entre cidadãos e autoridades públicas encarregadas do controle social no quadro do Estado de direito. Portanto, a crise do poder pessoal (mais propriamente, do patrimonialismo ancorado nas relações sociais) encontra-se na raiz destes casos extremos de justiça popular e vingança privada.

Pouco conhecidas, as ações de grupos de extermínio e de justiceiros parecem impulsionadas por um senso de justiça privada frente a circunstâncias consideradas social e culturalmente insuportáveis do ponto de vista da moralidade pública popular - como sejam tentativas ou atos consumados de estupro, sobretudo quando envolvem crianças e adolescentes, bem como roubos e homicídios voluntários de pessoas benquistas na comunidade -, tais modalidades de ação, concebidas como legítimas e moralmente imperativas, vêm contribuindo para exacerbar a explosão de litigiosidade que se espraia nos bairros onde predominam habitações populares. Trata-se de coletivos organizados em caráter permanente para execução sumária de suspeitos de cometimento de crimes. Predominam nas grandes metrópoles brasileiras, em especial em cidades como Rio de Janeiro e São Paulo. Cresceram notadamente a partir da década de 1980. Compõem-se de civis, cidadãos comuns, habitantes dos bairros populares, que agem sob contrato, acordo ou cumplicidade de outros agentes sociais notadamente policiais, comerciantes locais, moradores tradicionais --, os quais não se envolvem diretamente nas ações. Suas vítimas compreendem cidadãos, quase sempre originários da mesma localidade, considerados delinqüentes ou portadores de antecedentes criminais (Adorno e Cardia, 1999).

Igualmente desconhecidas são as chacinas ${ }^{17}$, associadas ou não ao tráfico de drogas, que parecem ter-se intensificado nos últimos cinco anos, em particular na periferia do Município de São Paulo e em sua região metropolitana. Suspeita-se que suas motivações principais residam na falta

público, atacada com paus e pedras, ultrajada e, não raro, tem membros ou órgãos mutilados ou decepados. No entanto, a maior parte destas ocorrências não resulta em desfecho fatal, mas em tentativa de linchamento.

16 Ainda é tímido o interesse dos pesquisadores pelo estudo deste fenômeno, no Brasil. Poucos estudiosos (sociólogos, historiadores e psicólogos sociais) vêm ocupando-se do exame dos casos, sobretudo noticiados pela imprensa periódica, nacional e local. Além do estudo realizado pelo Núcleo de Estudos da Violência (Pinheiro, Adorno, Cardia, citados), a mais completa pesquisa foi realizada por José de Souza Martins, do Departamento de Sociologia da USP (Martins, 1989, 1995 e 1996). Ver 
de pagamento de dívidas contraídas com o comércio e consumo de drogas. Certo ou não, tal modalidade de ação vem aumentando a intranqüilidade entre cidadãos procedentes das classes populares. Indefesos, carentes de proteção legal e policial, muitos destes populares, não comprometidos com as operações ilegais, vêem-se repentinamente à mercê da guerra entre quadrilhas.

Finalmente haveria que se computarem as mortes violentas provocadas por tensões nas relações intersubjetivas e que nada parecem ter em comum com a criminalidade cotidiana. Trata-se de um infindável número de situações, em geral envolvendo conflitos entre pessoas conhecidas, cujo desfecho acaba, muitas vezes até acidental e inesperadamente, na morte de um dos contendores. Compreendem conflitos entre companheiros e suas companheiras, entre parentes, entre vizinhos, entre amigos, entre colegas de trabalho, entre conhecidos que freqüentam os mesmos espaços de lazer, entre pessoas que se cruzam diariamente nas vias públicas, entre patrões e empregados, entre comerciantes e seus clientes. Resultam, em não poucas circunstâncias, de desentendimentos variados acerca da posse ou propriedade de algum bem, acerca de paixões não correspondidas, acerca de compromissos não saldados, acerca de reciprocidades rompidas, acerca de expectativas não preenchidas quanto ao desempenho convencional de papéis como os de pai, mãe, mulher, filho, estudante, trabalhador, provedor do lar, etc. No mais das vezes, revelam quanto o tecido social encontra-se sensível a tensões e confrontos que, no passado, não pareciam convergir tão abruptamente para um desfecho fatal ${ }^{18}$.

A esse quadro de violência interpessoal haveria que acrescentar a violência nas escolas (Spósito, 2001; Tavares dos Santos, 2001), a violência das galeras e bailes funks (Ceccheto, 1997; Viana, 1996), a violência doméstica (Izumino, 1998, entre outros), as gangues e quadrilhas de jovens 
(Diógenes, 1998), os assassinatos sistemáticos de homossexuais (Mott, 1996; Spagnol, 2001).

Desde a década passada, o impacto deste problema vem estimulando o desenvolvimento de pesquisas no domínio das ciências sociais. Em recente e exaustivo balanço analítico da literatura especializada, Zaluar (1999) demonstrou quanto já se avançou na caracterização do fenômeno, face ao pouco que se sabia em passado não distante. Não obstante, não parece ainda haver consenso entre os cientistas sociais - antropólogos, cientistas políticos e sociólogos - quanto às causas deste crescimento. Grosso modo, podem-se agrupar os esforços de explicação em, pelo menos, três direções:

a) mudanças na sociedade e nos padrões convencionais de delinqüência e violência;

b) crise do sistema de justiça criminal;

c) desigualdade social e segregação urbana.

\section{Mudanças na sociedade e nos padrões convencionais de delinqüência e violência}

Em particular nos últimos cinqüenta anos, assiste-se a uma aceleração de mudanças, jamais conhecida e experimentada anteriormente: novas formas de acumulação de capital e de concentração industrial e tecnológica; mutações substantivas nos processos de produção, nos processos de trabalho, nas formas de recrutamento, alocação, distribuição e utilização da força de trabalho com repercussões consideráveis nos padrões tradicionais de associação e representação sindicais; transbordamento das fronteiras do Estado-nação, promovendo acentuada mutação nas relações dos indivíduos entre si, dos indivíduos com o Estado e entre diferentes Estados, o que repercute na natureza dos conflitos sociais e políticos e nas modalidades de sua resolução (com a criação de legislação e tribunais paralelos ao Estado, por exemplo).

Essas mudanças repercutem também no domínio do crime, da violên- 
Sociologias, Porto Alegre, ano 4, no 8, jul/dez 2002, p. 84-135

cia e dos direitos humanos. Transformam-se os padrões tradicionais e convencionais de delinqüência anteriormente concentrados em torno do crime contra o patrimônio, via de regra cometido por delinqüentes que agiam individualmente ou, quando muito, em pequenos bandos e cuja ação tinha alcance apenas local. Na atualidade, cada vez mais, o crime organizado opera segundo moldes empresariais e com bases transnacionais, vai-se impondo, colonizando e conectando diferentes formas de criminalidade (crimes contra a pessoa, contra o patrimônio, contra o sistema financeiro, contra a economia popular). Seus sintomas mais visíveis compreendem emprego de violência excessiva mediante uso de potentes armas de fogo (daí a função estratégica do contrabando de armas), corrupção de agentes do poder público, acentuados desarranjos no tecido social, desorganização das formas convencionais de controle social. Na mesma direção, agrava-se o cenário das graves violações de direitos humanos. Como se sabe, o tráfico internacional de drogas é uma de suas modalidades mais significativas ${ }^{19}$.

\section{Crise no sistema de justiça criminal}

Não são poucos os estudos que reconhecem incapacidade do sistema de justiça criminal - agências policiais, Ministério Público, tribunais de justiça e sistema penitenciário - em conter o crime e a violência nos marcos do Estado democrático de direito. O crime cresceu e mudou de qualidade, porém o sistema de justiça permaneceu operando como o fazia há três ou quatro décadas atrás. Em outras palavras, aumentou sobremodo o fosso entre a evolução da criminalidade e da violência e a capacidade de o Estado impor lei e ordem. Os sintomas mais visíveis deste cenário são as dificuldades e desafios enfrentados pelo poder público em suas tarefas constitucionais de deter o monopólio estatal da violência, sintomas repre- 
sentados pela sucessão de rebeliões nas prisões, grande parte dessas ocorrências organizadas de dentro das prisões por dirigentes do crime organizado como o Comando Vermelho e Terceiro Comando, no Rio de Janeiro e o Primeiro Comando da Capital, em São Paulo, responsável pelo motim simultâneo de vinte e nove grandes prisões, no Estado de São Paulo, em janeiro de 2001. Do mesmo modo, cada vez mais é flagrante a ousadia no resgate de presos, a existência de áreas das grandes cidades onde prevalecem as regras ditadas, por exemplo, pelo tráfico de drogas em detrimento da aplicação das leis.

Este cenário ainda estaria incompleto se a ele não se agregasse acentuada crise no sistema de justiça criminal. Na década de 1980, o acúmulo histórico de problemas na área se acentuou. O profundo hiato entre o crescimento da violência e o desempenho do sistema de justiça criminal agravou-se em virtude dos novos problemas de reforma e controle institucional propostos pela transição política e pela consolidação do regime democrático. E o agravamento se dá a despeito das iniciativas de reforma da legislação penal promovidas pelo governo federal e de reaparelhamento do sistema de justiça criminal executadas pelos novos governos estaduais civis que se seguiram à queda do regime autoritário. Neste domínio, convém mesmo sublinhar que algumas avaliações sugerem a queda dos investimentos em segurança pública e justiça durante toda a década de 1980. Além do mais, pressionados a rapidamente promoverem a desmontagem dos aparelhos repressivos que tiveram vigência durante o regime anterior e ao mesmo tempo exercerem pertinaz controle sobre os abusos de poder cometidos por agentes públicos (policiais militares nas ruas, nas habitações populares e nas instituições de reparação social; policiais civis nas delegacias e distritos policiais; guardas de prisão nas instituições carcerárias), os novos governos estaduais demoraram a responder com eficiência aos novos problemas decorrentes do crescimento e da mudança do perfil da criminalidade urbana violenta. Trata-se de um 
cenário que adentra os anos 90.

O resultado mais visível dessa crise do sistema de justiça criminal é, sem dúvida, a impunidade penal ${ }^{20}$. Os poucos estudos disponíveis (Soares e outros, 1996; Adorno, 1994 e 1995; Pinheiro, Adorno, Cardia e outros, 1999; Castro, 1993) sugerem que as taxas de impunidade são mais elevadas no Brasil do que em outros países, como na França (Robert et al., 1994), na Inglaterra (Jefferson e Shapland, 1993), nos Estados Unidos (Gurr, 1989; Donziger, 1996). No Brasil, tudo parece indicar que as taxas de impunidade sejam mais elevadas para crimes que constituem graves violações de direitos humanos, tais como: homicídios praticados pela polícia, por grupos de patrulha privada, por esquadrões da morte e/ou grupos de extermínio, ou ainda homicídios consumados durante linchamentos e naqueles casos que envolvem trabalhadores rurais e lideranças sindicais. Do mesmo modo, parecem altas as taxas de impunidade para crimes do colarinho branco cometidos por cidadãos procedentes das classes médias e altas da sociedade.

A conseqüência mais grave deste processo em cadeia é a descrença dos cidadãos nas instituições promotoras de justiça, em especial encarregadas de distribuir e aplicar sanções para os autores de crime e de violência. Cada vez mais descrentes na intervenção saneadora do poder público, os cidadãos buscam saídas. Aqueles que dispõem de recursos apelam, cada vez mais, para o mercado de segurança privada, um segmento que vem crescendo há, pelo menos, duas décadas. Em contrapartida, a grande maioria da população urbana depende de guardas privados não profissionalizados, apóia-se perversamente na "proteção" oferecida por traficantes locais, ou procura resolver suas pendências e conflitos por conta própria.

20 A carência de dados estatísticos e de levantamentos sistemáticos periódicos impede de conhecer a efetiva magnitude e extensão da impunidade penal no Brasil. A despeito dessas limitações, algumas avaliações parciais já indicam algo a respeito. Indicam, por exemplo, que determinadas áreas de comportamento, embora protegidas pelas leis penais, estão praticamente isentas de sua aplicação. Crimes como furtos ou que compreendem a chamada pequena criminalidade não chegam a ser investigados. Em decorrência, seus possíveis autores não são identificados e conseqüentemente processados e condenados. Mesmo casos mais graves como roubos, tráfico de drogas e até homicídios, compõem as chamadas "áreas de exclusão penal". A maior ou menor capacidade de serem esses crimes investigados vai depender de uma série de fatores, como interesse das agências policiais em investigá-los, pressões da opinião pública em exigir resposta do sistema de justiça criminal, tráfico de influências diversas procu- 
Tanto num como noutro caso, seus resultados contribuem ainda mais para enfraquecer a busca de soluções proporcionada pelas leis e pelo funcionamento do sistema de justiça criminal.

Pesquisa Nacional por Amostra de Domicílios (IBGE-PNAD, 1990) investigou o comportamento social face à Justiça Pública. Os resultados são surpreendentes. Eles revelaram que, no período de outubro de 1983 a setembro de $1988,55,20 \%$ de todas as pessoas que se envolveram em diferentes conflitos (trabalhista, criminal, conjugal, desocupação de imóvel, pensão alimentícia, conflito de vizinhança, conflitos por posse de terra, cobrança de dívida, herança), não recorreram à justiça. Entre estes, o motivo preponderantemente alegado foi: "resolveu por conta própria". $42,69 \%$ das razões alegadas para não interpor ação judicial se classificam nessa ordem de motivos. Acresce notar que $23,77 \%$ dos entrevistados revelaram não confiar nos serviços jurídicos e judiciais. Esses dados são indicativos da baixa confiabilidade nas instituições públicas e, em particular, na Justiça. A Justiça não é vista, pelos cidadãos, como instrumento adequado de superação da conflitualidade social.

Institutos de pesquisa de opinião, como Vox Populi e Datafolha, com freqüência têm sondado as inquietações públicas com relação ao crime e à violência. Em meados da década passada, sondagem de opinião Jornal do Brasil/Vox Populi, realizada entre 13-16 de abril de 1995, conclui na mesma direção:

73\% dos brasileiros não confiam na Justiça. As respostas dadas ao questionário mostraram que, no entender da maioria da população, a lei não é igual para todos, embora esse princípio esteja estabelecido no Artigo 5o. da Constituição. Para 82\% dos 3.075 entrevistados, a lei é mais rigorosa para alguns, privilegiando outros. O Vox Populi perguntou se negros e brancos, pobres e ricos recebem o mesmo tratamento para crimes iguais. Para 80\%, não há dúvida: o pobre será 
julgado mais rigorosamente; e 62\% acreditam que o negro receberá punição mais pesada (Cf. Jornal do Brasil. Rio de Janeiro, 28/04/95, p. 1).

Recente inquérito, realizado pelo Datafolha para o conjunto do país, revelou que o número de brasileiros que consideram a violência o mais grave problema do país duplicou em apenas dois meses. Em dezembro de 2001, representavam 10\%; em fevereiro de 2002, esta proporção saltou para $21 \%$. A despeito de que as estatísticas oficiais de criminalidade venham indicando tendência à estabilização das ocorrências de maior gravidade e de maior incidência, a explosão do medo e da insegurança parece ter vindo na esteira da onda de seqüestros, sobretudo no Estado de São Paulo, e do assassinato de dois Prefeitos, ambos do Partido dos Trabalhadores - PT, o de Campinas e o de Santo André, importantes municípios industriais desse Estado $^{21}$. O mesmo levantamento indica que $12 \%$ de pessoas declararam viver em moradias onde há armas de fogo, muitas delas irregulares, dado que o número de armas registradas é de 2,91 milhões, um volume seguramente abaixo de estimativas esperadas. Em 1999, a proporção de pessoas que haviam feito essa declaração era de $8 \%$. Não é de surpreender que 59\% dos entrevistados tenham manifestado mais medo da polícia do que confiança. Não é estranho também a subnotificação dos crimes: $64 \%$ das vítimas de roubo e $71 \%$ das vítimas de furto não apresentaram queixa à polícia (Folha de São Paulo, C-1/4, 10/03/2002).

Este cenário de desconfiança revela também suas nuanças. Em sucessivos estudos sobre a representação da violência, Cardia observou mudanças sensíveis, porém significativas. Os primeiros levantamentos datam de 1989-1991. Foram realizados em São Paulo pela Comissão Justiça e Paz, órgão das pastorais católicas. Revelaram acentuada desconfiança nos direitos humanos e acentuada imagem negativa dos presos, o que levou à

rando dissuadir investigações em função da importância social dos envolvidos, etc.

$21 \mathrm{O}$ assassinato de figuras políticas introduz a suspeita de que a sociedade brasileira estaria adentrando uma era de 
conclusão de que estava em curso, na sociedade brasileira, um processo de exclusão moral, pelo qual delinqüentes e infratores das leis penais eram percebidos como pessoas não apenas destituídas do direito a ter direitos, mas, mais que isso, também destituídas de humanidade, razão por que poderiam até ser eliminadas sem julgamento. No penúltimo dos levantamentos, realizado em dez capitais de Estados da federação, Cardia examinou, entre outras questões, as imagens a respeito do Plano Nacional de Direitos Humanos. Constatou que, mesmo entre aqueles que persistem associando direitos humanos como proteção para bandidos, não há mais forte apoio à aplicação de medidas extrajudiciais para contenção da delinqüência (Cardia, 1994, 1999 e 2001). Grossi Porto, em seus estudos sobre violência policial, revelou quanto permanece frágil o equilíbrio entre segurança, violência e eficácia da ação policial (Porto, 2001).

Sinal dos novos tempos, a desconfiança nas instituições de justiça, em especial no desempenho da polícia em suas tarefas de repressão da violência, não se traduz necessariamente em aprovação à violência; ao contrário, fala-se cada vez com maior freqüência na necessidade de observância rigorosa das leis e no aperfeiçoamento das instituições de justiça, ainda que os fatos cotidianos pareçam desmentir estas tendências. Recentes mortes de 12 supostos delinqüentes (supostos, porque nem todos parecem dispor de antecedentes criminais), em ação praticada pela Polícia Militar do Estado de São Paulo com o propósito de prevenir planejada ação de ataque a um aeroporto local, mereceu imediata acolhida popular sob o argumento de que, finalmente, a polícia estava sendo eficiente.

\section{Violência, desigualdade social e segregação urbana}

Há cerca de três décadas, o debate e a reflexão sobre a violência e o crime, no Brasil, estavam apenas iniciando. Tratava-se, em verdade, de um debate suscitado pela esquerda e pelos primeiros defensores de direitos humanos. Embora a violência fosse um fenômeno endêmico na sociedade 
Sociologias, Porto Alegre, ano 4, no 8, jul/dez 2002, p. 84-135

brasileira, sua visibilidade ganhou foro público durante a transição da ditadura para a democracia. O fim do regime autoritário havia deixado mostras de que a violência institucional sob a forma de arbítrio do Estado contra a dissidência política não se restringia à vigência do regime de exceção. Há muito, desde os primórdios da República, trabalhadores urbanos pauperizados eram vistos como pertencentes às classes perigosas e passíveis de estreito controle social que incluía detenções ilegais, aplicação de torturas e maus tratos nas delegacias e postos policiais e perseguições arbitrárias. Quando, em meados dos anos 70, começaram a aparecer as primeiras inquietações com a persistência da violência institucional como forma rotineira e organizada de conter os crimes, acreditava-se que o crime, a criminalidade e a brutalidade contra o delinqüente tinham raízes estruturais. Devia-se ao capitalismo, às estruturas de exploração, dominação e exclusão inerentes a este modo de organização societário. Em decorrência, estabelecia-se uma sorte de associação mecânica, por assim dizer, entre pobreza e violência. Quanto maior a pobreza, maior a violência. A violência urbana aparecia então como expressão de lutas entre as classes dominantes e o conjunto dos subalternos. Por conseguinte, também, os criminosos compareciam às representações sociais como vítimas potenciais de um modelo fundado na injustiça social. Compreendiam trabalhadores urbanos arrastados, contra sua vontade e natureza, para o mundo do crime e da violência. Bastava, para tanto, visitar o cenário social das prisões para confirmar essa tese. Superar esse cenário significava, antes de tudo, introduzir radicais transformações na sociedade brasileira com o propósito de erradicar a pobreza, de modo a eliminar as raízes da violência estrutural. Estudo de Pezzin (1986) confirmava correlações positivas e significativas entre urbanização, pobreza e desemprego com a criminalidade patrimonial, no Município de São Paulo.

Não demorou muito para que as forças conservadoras, parte das quais herdeira ou comprometida com o regime autoritário, se articulasse para 
contestar esses argumentos. Insistiam que a violência antes tinha a ver com a falência de políticas retributivas, fundadas na repressão dos crimes e na aplicação rigorosa de leis penais, do que na falência de políticas distributivas. Argumentavam que, mesmo que se lograsse alcançar uma sociedade mais justa, os crimes continuariam a crescer. Esse confronto de entendimentos, constrangeu as forças políticas progressistas - liberais, liberal-democratas, socialistas -, bem como pesquisadores, a reverem seus argumentos. Logo se percebeu que a associação mecânica entre pobreza, crime e violência suscitava mais problemas do que os solucionava. Afinal, embora a maior parte dos delinqüentes proviesse das classes trabalhadoras urbanas pauperizadas, maior parte desses trabalhadores, submetidos às mesmas condições sociais de vida, não enveredava pelo mundo do crime. O problema não residia na pobreza, porém na criminalização dos pobres, vale dizer, no foco privilegiado conferido pelas agências de controle social contra a delinqüência cometida por cidadãos pobres. Polícia e justiça pareciam revelar maior rigor punitivo contra negros, pobres, migrantes (Adorno, 1994 e 1995). Ainda em fins da década de 1980, Box (1987) realizou instigante estudo sobre as relações entre recessão, crime e punição. Suas conclusões indicaram correlações entre crise econômica e tendências à superpopulação prisional, conclusão a que também chegou mais recentemente Wacquant (1999).

A tese que sustentava relações de causalidade entre pobreza, delinqüência e violência está hoje bastante contestada em inúmeros estudos. Em particular, os estudos de Zaluar (1994 e 1999), de Coelho (1987), de Beato (1998) e Sapori e Wanderley (2001) contestam profundamente essa associação. Observando o comportamento da criminalidade violenta na região metropolitana do Rio de Janeiro entre 1980 e 1983, período caracterizado pela crise econômica e por elevadas taxas de desemprego, CoeIho constatou o declínio das taxas de homicídio, de estupro e de roubo. Estudando os determinantes da criminalidade no Estado de Minas Gerais, 
Beato concluiu que os municípios de menor incidência de crimes são justamente os mais pobres; ao contrário, a riqueza e a circulação de dinheiro estão mais associadas à maior incidência e prevalência de crimes, em especial os violentos. Beato e Reis (1999) não identificaram qualquer correlação positiva entre as taxas de desemprego urbano no Município de Belo Horizonte, capital do Estado de Minas Gerais, e as taxas de criminalidade. Sapori e Wanderley, por sua vez, observando quatro regiões metropolitanas do Brasil - Rio de Janeiro, São Paulo, Belo Horizonte e Porto Alegre, capital do Estado do Rio Grande do Sul - aplicaram testes estatísticos (medida de Granger e testes econométricos), não encontraram indícios significativos de que as variações nas taxas de desemprego implicassem variações, presentes ou futuras, nas taxas de criminalidade. Por fim, em seu estudo sobre as relações entre renda, desigualdade social e violência letal, Cano e Santos (2001) afirmam não ser possível identificar clara influência da renda sobre as taxas de homicídio.

No entanto, esse debate não parece, sob qualquer hipótese, estar concluído. Cano e Santos inventariam obstáculos metodológicos, alguns dos quais relacionados às fontes de informações que impedem rigorosa comparabilidade de dados; outros relacionados ao eixo que sustém a maior parte dos estudos: "a hipótese de que a pobreza e a desigualdade aumentam a violência se fundamenta em teorias que se referem basicamente aos autores de crimes, não às vítimas" (p. 81). Monteiro e Zaluar (1998), observando estimativas de mortalidade indireta, a partir de dados do censo de 1991, concluíram que o risco de ser vítima de violência letal entre crianças e adolescentes de 5 a 20 anos dobra quando a mãe pertence a uma família cuja renda per capita é inferior a um salário mínimo. O risco é também maior para mães que vivem em favelas, comparativamente ao resto da população. Ademais, os estudos que exploram relações entre desemprego e crime se baseiam em dados sobre o mercado formal de trabaIho. Sabe-se que as recentes transformações na economia brasileira e na 
flexibilização das relações trabalhistas não apenas aumentaram as taxas de desemprego aberto, mas também vêm contribuindo para o aumento das taxas de desemprego disfarçado e para o inchaço do mercado informal, de cuja magnitude não temos preciso conhecimento. Estudos sobre população prisional indicam proporções elevadas de delinqüentes procedentes do mercado informal que jamais tiveram carteira profissional assinada ou contrato formal de trabalho firmado (Brant, 1994; Adorno e Bordini, 1991).

Recente estudo (Paes de Barros e outros, 2000) desenvolve a hipótese segundo a qual,

o Brasil não é um país pobre, mas um país com muitos pobres. Em segundo lugar, acreditamos que os elevados niveis de pobreza que afligem a sociedade encontram seu principal determinante na estrutura da desigualdade brasileira - uma perversa desigualdade na distribuição da renda e das oportunidades de inclusão econômica e social (p. 123).

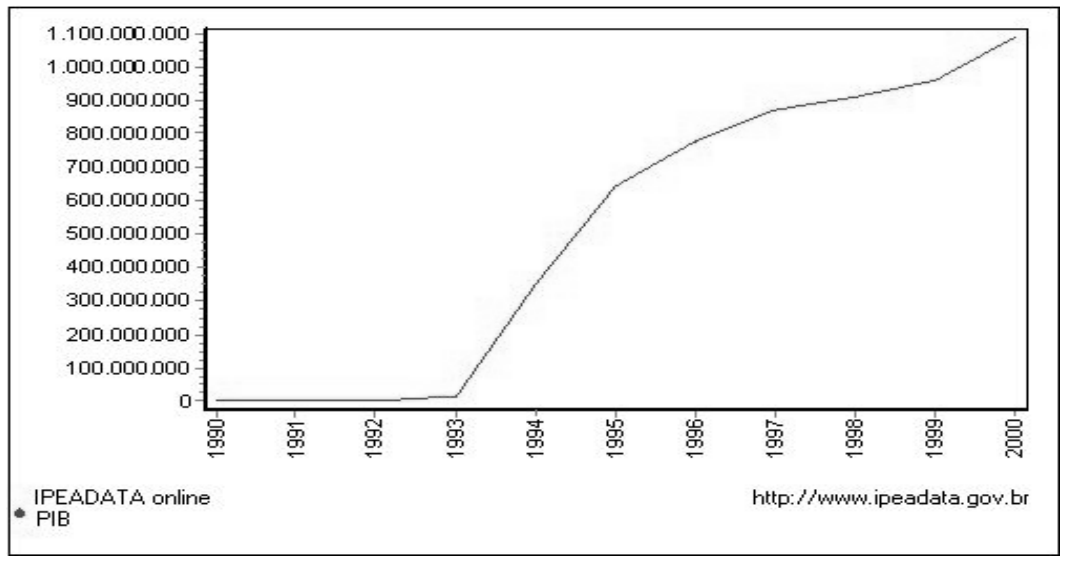

De fato, conforme sugere o gráfico 4 abaixo, o Produto Interno Bruto 
Sociologias, Porto Alegre, ano 4, no 8, jul/dez 2002, p. 84-135

cresceu acentuadamente no período de 1990-2000.

Gráfico 4. Riqueza nacional versus desigualdade social

No entanto não há como deixar de reconhecer relações entre a persistência, na sociedade brasileira, da concentração da riqueza, da concentração de precária qualidade de vida coletiva nos chamados bairros periféricos das grandes cidades e a explosão da violência fatal. Mapas da violência, realizados para algumas capitais brasileiras na década passada, indicavam que as taxas de homicídios eram sempre e flagrantemente mais elevadas nessas áreas do que nos bairros que compõem o cinturão urbano meIhor atendido por infraestrutura urbana, por oferta de postos de trabalho, por serviços de lazer e cultura. Recente estudo sugeriu que, no Município de São Paulo, a maior concentração de homicídios estava associada ao congestionamento habitacional, fenômeno característico dos bairros onde habitam preferencialmente trabalhadores urbanos de baixa renda (Cardia e Schiffer, 2000).

Tudo isso parece indicar, nesses bairros, maior predisposição para desfechos fatais em conflitos sociais, interpessoais e intersubjetivos.

Muitos outros dados de desempenho econômico e crescimento da riqueza nacional poderiam ser aqui agregados. Em especial, convém lembrar que o Plano Real, instituído no Governo Itamar Franco (1992-93), que sucedera ao presidente Collor de Mello, logrou reduzir e controlar a inflação, contribuindo para a estabilidade da moeda e do mercado financeiro, aspectos que seriam ainda mais valorizados nos governos subseqüentes (Governo Fernando Henrique Cardoso, 1993-1997 e 1998 até o presente).

A despeito disso, permaneceu acentuado o hiato entre direitos civis, sociais e econômicos. Esse hiato manifesta-se sobretudo através de um conflito entre as exigências de democracia política e as de democracia social. Se hoje, na sociedade brasileira, pode-se dizer que o processo de transição democrática promoveu a ampliação da participação e da representação política, esse movimento de ampliação dos direitos políticos não 
resultou em ampliação da justiça social. O aprofundamento das desigualdades sociais persiste sendo um dos grandes desafios à preservação e respeito dos direitos humanos para a grande maioria da população.

Neste horizonte social e político, convém lembrar que o Brasil continua a ter o pior índice de concentração de renda entre todos os países do mundo com mais de dez milhões de habitantes. Há fortes disparidades regionais entre os Estados do Sudeste e Nordeste. Os principais indicadores deste cenário podem ser ilustrados como segue ${ }^{22}$ :

- o Produto Interno Bruto (PIB), indicador do volume de atividades econômicas, foi da ordem de $\bigcup \$ 464,6$ bilhões no ano de 1990. Projeção para o ano de 1992 indicava a seguinte participação regional na composição do PIB: $56,18 \%$, região Sudeste; $16,74 \%$, região Sul; $15,86 \%$, região Nordeste; 5,69\%, região Centro-Oeste; e 5,53\%, região Norte;

- a esperança média de vida para o ano de 1990 é de 65,49 anos. Este índice é ligeiramente menor no Nordeste (64,22 anos), comparativamente aos índices correspondentes às regiões Sul (68,68 anos) e Sudeste (67,53 anos). A esperança média de vida é maior nos estratos de rendimento superior. Dados relativos ao ano de 1984 indicavam que a esperança média de vida era de 57,5 anos entre aqueles que auferiam até um salário mínimo, ao passo que, entre aqueles que auferiam até cinco salários mínimos, esse índice se elevava para 73,4 anos. Mais surpreendente é verificar que o grupo mais rico do Sudeste revela uma esperança média de vida superior em 23,5 anos à esperança média de vida dos mais pobres da região Sudeste;

- disparidades também podem ser observadas no que concerne à mortalidade infantil. A taxa de mortalidade infantil no Brasil, para o ano de 1990, é de 51,6 por mil nascidos vivos. Enquanto na região Sul essa taxa

\footnotetext{
"colombiazação", na qual movimentos de resistência política e de luta armada se associam ao crime organizado para impor seus interesses. Trata-se de matéria controvertida.

22 Os dados que se seguem foram extraídos e selecionados do Relatório brasileiro preparado para a Cúpula Mundial para o
} 
Sociologias, Porto Alegre, ano 4, no 8, jul/dez 2002, p. 84-135

é da ordem de 26,7/mil nascidos vivos, no Nordeste é de 88,2/mil nascidos vivos. Do mesmo modo, essa taxa é mais alta entre os estratos de rendimento inferior. Assim, entre as famílias com renda de até um salário mínimo, a taxa de mortalidade infantil alcançava 75,2/mil nascidos vivos. Já entre aquelas com renda superior a um salário mínimo, essa taxa correspondia a 33,3/mil nascidos vivos. Convém observar que, embora essa taxa tenha decrescido acentuadamente ao longo da década de 1980, ela é ainda elevada, conforme se pode depreender a partir de comparações internacionais. Dados relativos ao ano de 1991 indicam uma taxa de 25/mil nascidos vivos na Argentina, 17/mil nascidos vivos no Chile, 23/mil nascidos vivos na Colômbia, 36/mil nascidos vivos no México, 34/mil nascidos vivos na Venezuela (World Bank, Table of Social and Economic Conditions, 1992);

- conquanto a década de 1980 tenha acusado substantiva expansão do saneamento básico, sua distribuição não alcançou igualmente as áreas urbanas e as rurais, bem como as diferentes regiões do país, manifestando-se acentuadas disparidades. A título de ilustração: no ano de 1990, apurou-se que $63,5 \%$ da população brasileira tinha acesso ao abastecimento de água no interior do próprio domicílio. No entanto essa proporção era significativamente superior para os domicílios urbanos $(81,6 \%)$ por comparação aos domicílios rurais (12\%). Esta disparidade é ainda maior no caso das instalações sanitárias. Enquanto 48,5\% dos domicílios urbanos eram servidos por tais instalações, apenas o eram $5 \%$ dos domicílios rurais. É de se destacar os efeitos deste quadro sobre a saúde pública. Conforme aponta o relatório citado,

entre famílias com renda per capita mensal de até meio salário mínimo, a taxa de mortalidade infantil em famílias que dispunham de infra-estrutura familiar adequada, em termos de rede geral de água e de esgoto ou fossa séptica, era de 51,6 por mil nascidos vivos; no segundo caso, das famílias sem acesso a essa infra-es- 
trutura, a taxa elevava-se para 107,9 por mil nascidos vivos (Lampreia e outros, 1995, p. 13).

Conseqüências do acesso desigual ao saneamento básico refletem-se igualmente na distribuição desigual de doenças infectocontagiosas, típicas de cenários de pobreza, e de doenças crônicas e degenerativas, próprias de cenários sociais caracterizados pelo desenvolvimento e pela generalização do bem-estar no interior de uma população determinada;

- no que concerne à escolarização formal, os anos 90 herdaram 20,2 miIhões de analfabetos com dez ou mais anos de idade, a despeito dos avanços que se verificaram no domínio da educação. Esse contigente representa a proporção de $12,92 \%$ da população brasileira. Trata-se de uma proporção próxima de países como Colômbia, México e Venezuela. No entanto, uma proporção superior à de outros países latinoamericanos como Argentina (5\%), Chile (7\%) e Uruguai (4\%) (Cf. World Bank, Table of Social and Economic Conditions, 1992). O Brasil é o sétimo país em número de analfabetos. A previsão do Instituto Brasileiro de Geografia e Estatística (IBGE) é de que, somente no ano de 2030, é que será possível erradicar completamente o analfabetismo entre os cidadãos brasileiros (Folha de São Paulo, 3-6, 08/09/95) 23. No terreno da escolarização formal, as disparidades regionais também são gritantes. Na região Sudeste, a taxa de analfabetismo de pessoas de dez anos e mais é da ordem de 10,9\% do conjunto da população; no Nordeste, esta proporção é três vezes maior, alcançando a proporção de $35,9 \%$ da população;

- estima-se a existência de nove milhões de famílias enfrentando o problema da fome. Somente no Nordeste localizam-se 17,2 milhões dos atin-

Desenvolvimento Social, realizada em Copenhague, em março de 1995. Vide Lampreia e outros (1995). Há, contudo, documentos mais atualizados que já apontam sensíveis mudanças em alguns aspectos da questão social brasileira, em especial no tocante à escolaridade.

23 A mesma fonte informa que o índice oficial de analfabetos no país é, para o ano de 1991, de 20,07\%, correspondente a 19.233.758 pessoas com mais de 15 anos de idade. Trata-se de uma proporção sujeita a reparos, tendo em vista a magnitude 
gidos, ao passo que, na região sudeste, esse contingente é da ordem de 7,9 milhões de pessoas (Lampreia e outros, 1995). Estudo realizado por pesquisador do Departamento de Nutrição da Faculdade de Saúde Pública da USP identificou $15,4 \%$ de crianças brasileiras, entre 24 e 59 meses, portadoras de nanismo nutricional ${ }^{24}$. A despeito dos investimentos sociais em saneamento básico e em campanhas de vacinação, no conjunto os investimentos públicos em saúde vêm declinando. Assim, em 1980, o governo federal havia gasto US $\$ 78,58$ per capita; treze anos mais tarde (1993), havia gasto US\$65,40 per capita ${ }^{25}$. Nesta mesma área, os investimentos brasileiros, em 1990, correspondendo a 2,76\% do BIB, estão atrás dos investimentos feitos em outros países latinoamericanos como Costa Rica, Uruguai, Argentina, Panamá, Chile e México (Cf. World Bank, 1990). Resultados dessa retração em investimentos na área de saúde revelam-se, entre outros aspectos, na saúde bucal: apenas 40\% dos jovens dispõem de dentição completa até os 18 anos; $72 \%$ de pessoas entre 50-59 anos já extraiu todos os dentes; crianças, na faixa de 12 anos, manifestam índice de CPO (dentes permanentes cariados, perdidos ou obturados) de 6,5 - um dos mais altos do mundo, indicativo de sinais epidêmicos -, quando o limite aceito e reconhecido pela Organização Mundial de Saúde (OMS) é de 3,0. No mais, convém salientar, no Brasil é precoce a privatização dos serviços de saúde, ao que se vem associar um modelo de saúde pública centrado em torno do atendimento hospitalar, o que, no limite, contribui para o agravamento dos problemas existentes (Lampreia e outros, 1995). Nunca é demais sublinhar

da população brasileira no período. Convém observar, outrossim, que o critério utilizado pelo IBGE para definir o cidadão alfabetizado é "saber ler e escrever um bilhete simples", critério este criticado por não poucos educadores e por ONGs, sob o argumento de que ele deixa à margem um grande contingente de pessoas efetivamente analfabetas. Cf. Folha de S. Paulo, 3$6,08 / 09 / 95$.

24 Esta informação corrige dado contido no Relatório "Investimento em Saúde: Indicadores de Desenvolvimento Mundiais", divulgado pelo Bird em 1995, para o qual a proporção de crianças, naquela faixa etária, portadoras de nanismo nutricional era da ordem de 29\%. Segundo Carlos Monteiro, professor e pesquisador da Faculdade de Saúde Pública da USP, o Bird baseou suas informações em pesquisa com crianças nordestinas, cujo padrão nutricional é inferior à média nacional. Segundo o mesmo pesquisador, entre 1975 e 1989, verificou-se evolução do estado nutricional das crianças brasileiras, motivada por investimentos 
que cerca de $23 \%$ da população brasileira desfruta de seguro privado de saúde. Os restantes 77\% (118 milhões de brasileiros) dependem dos recursos públicos. Mais grave ainda é constatar distorções na aplicação de recursos públicos, motivada pela ausência de uma efetiva política de prioridades. Estudo realizado pelo Banco Mundial revelou que, no início da década de 1980, o Inamps consumiu cerca de 15\% de seu orçamento com despesas decorrentes do envio ao exterior de 127 crianças, com seus acompanhantes, para realizar tratamento médico inexistente no país. No mesmo sentido, consumiu $6 \%$ com a manutenção de um universo inferior a 2 mil pacientes de hemodiálise. Em contrapartida, acumularam-se problemas e dificuldades na implementação de medidas de atenção médica primária (O Estado de São Paulo, 11/07/93, p. 26);

- é crescente a concentração da renda nos últimos trinta anos. Este é, sem dúvida, o índice que melhor traduz as disparidades regionais e as distânci-

\begin{tabular}{l|cccc}
\hline Ano & Coeficiente Gini & Índice & $\mathbf{1 0 + / 1 0}-$ & Índice \\
\hline 1960 & 0,50 & 100 & 34 & 100 \\
1970 & 0,60 & 120 & 40 & 118 \\
1980 & 0,59 & 118 & 47 & 138 \\
1990 & 0,63 & 126 & 78 & 229 \\
\hline
\end{tabular}

as entre classes sociais. A tabela 2, a seguir transcrita, fala por si própria:

Tabela 2. Evolução dos índices de concentração de renda - Brasil - 19601990

Fonte: Barros \& Mendonça (1993). Apud Lampreia \& outros (1995).

Estes dados indicam que, em 1960, a renda apropriada pelos 10\% mais ricos era 34 vezes superior à renda apropriada pelos 10\% mais pobres. Trinta anos mais tarde, aprofundaram-se as desigualdades na distri- 
buição da renda pois esse gap se eleva para 78 vezes (Cf. Lampreia et al., 1995). Vale notar que, nos últimos trinta anos, estudos demonstram o crescimento da renda beneficiando em termos absolutos todos os grupos sociais. Tais estudos sugerem que houve inequívoca melhoria do bem-estar. No entanto, reconhecem que os ganhos foram alocados de modo tão desproporcional que teve por efeito acentuar pesadamente as desigualdades sociais. Dito de outro modo, o crescimento do bem-estar e a diminuição relativa da pobreza não lograram neutralizar as profundas disparidades socioeconômicas (Rocha, 1990; Hoffmann, 1995; Barros \& Mendonça, 1995). O perfil da distribuição da renda para o ano de 1990 permite aquilatar a magnitude dessa desigualdade: os $10 \%$ dos mais ricos apropriam-se de $48,1 \%$, isto é, quase metade de toda a renda nacional, e os $1 \%$ mais ricos detêm 13,9\%; em contrapartida, os $10 \%$ mais pobres apropriam-se de tão somente $0,8 \%$, e os $50 \%$ mais pobres detêm $12,1 \%$ do total de rendimentos (Lampreia et al., 1995, p. 16) ${ }^{26}$.

Estudo já mencionado, realizado por Paes de Barros e outros (2000) indica que, a despeito dos ganhos trazidos pelo Plano Real, a desigualdade de renda no ano de 1998 é um dos mais elevados das últimas décadas. Em outras palavras, a despeito de avanços no campo da escolaridade e

sociais nas áreas de saneamento básico e campanhas de vacinação. Observe-se, a propósito, que o PNUD anota como 15\% a porcentagem de crianças afetadas por nanismo nutricional. Cf. Estado de S. Paulo, 11/07/93, p. 25.

25 Informações prestadas por André Cézar Médici, coordenador de Políticas Sociais do Instituto de Estudos do Setor Público do Governo do Estado de São Paulo. São Paulo, Folha de S. Paulo e O Estado de S. Paulo, julho de 1993.

26 O Instituto de Pesquisa Econômica Aplicada (IPEA), do Ministério do Planejamento, acaba de concluir estudo no qual constata sensível melhoria na distribuição da renda. A participação dos 50\% mais pobres elevou-se de 10,4\% (setembro de 1994) para $11,6 \%$ (setembro de 1995). No mesmo período, decresceu a participação dos $20 \%$ mais ricos na apropriação da renda (de $65,7 \%$ 


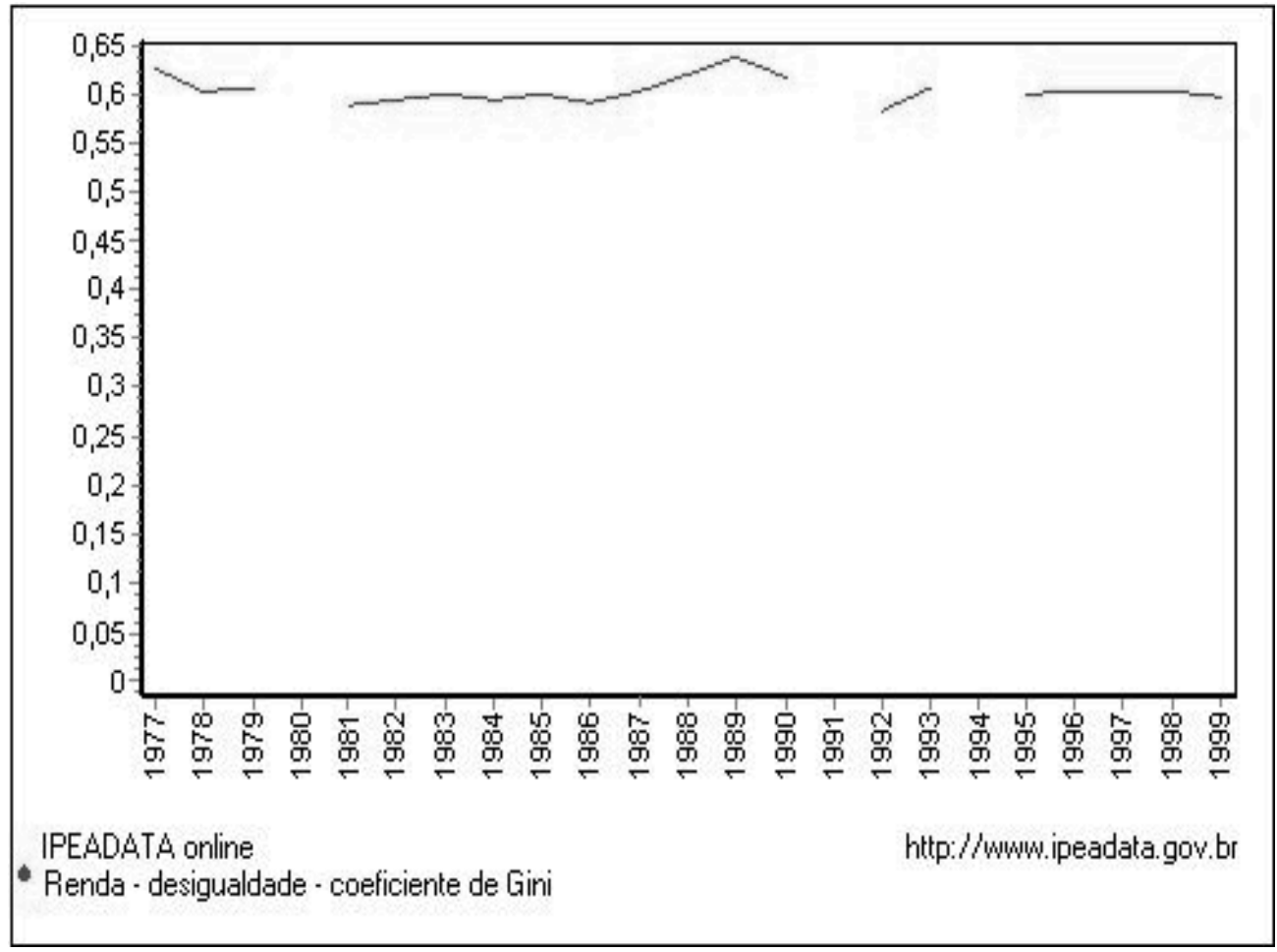

Gráfico 5 
Sociologias, Porto Alegre, ano 4, no 8, jul/dez 2002, p. 84-135

escolarização verificados ao longo dos anos 90, a concentração da renda e da riqueza mantiveram-se nos mesmos padrões de cerca de três ou quatro décadas atrás. O gráfico 5, a seguir, ilustra esta tendência:

- as disparidades na distribuição da renda espelham, a par da concentração da riqueza em particular sob a forma de propriedade privada da terra e do solo urbano, o acesso desigual ao mercado de trabalho. De início convém ressaltar que, no Brasil, a despeito dos interditos constitucionais, cerca de 16,9\% das crianças entre dez a 14 anos já trabalham, o que revela o aproveitamento do trabalho infantil como estratégia de sobrevivência familiar. Segundo dados compilados pelo Relatório brasileiro sobre desenvolvimento social (Lampreia et al., 1995), para o ano de 1981, a participação de pessoas com dez anos ou mais no mercado formal de trabalho compreendia $54,23 \%$ da população economicamente ativa. O mercado informal abrigava $28,12 \%$ dos trabalhadores. Trabalhadores por conta própria representavam o percentual de 25,95\% da ocupação total, e a taxa de desemprego era de 6,5\%. Ao longo da década de 1990, este cenário manteve-se relativamente estável, apesar de algumas tendências que se acentuaram, como a informalização progressiva das relações de trabalho (crescimento da ordem de 8\% entre 1989 e 1992), a elevada taxa de rotatividade de mão-de-obra, a intensidade de emprego de trabaIhadores não-qualificados ou de baixa qualificação e a grande heterogeneidade de situações de emprego e de relações de trabalho. Pode-se inferir, a partir desse cenário social, que não se logrou universalizar o modelo contratual de organização societária no Brasil. A expansão acelerada do mercado informal, fragilizando a institucionalização das relações de trabalho e agravando as situações possíveis de pobreza parecem constituir indicadores desta experiência brasileira de "modernidade inconclusa". 
Além do mais, a desigualdade social e a concentração de riqueza, fenômenos que persistiram ao longo dos anos 90 a despeito do crescimento da riqueza e das profundas mudanças por que vem passando a economia brasileira, coincidiram com a crise fiscal, mais propriamente com fortes restrições ao Estado, para reduzir a violência através do estímulo ao desenvolvimento econômico-social, à expansão do mercado de trabalho e à garantia de um mínimo de qualidade de vida para o conjunto da população. Se a crise econômica afeta a qualidade de vida de imensas populações urbanas, sobretudo de seus segmentos pauperizados e de baixa renda, ela afeta também a capacidade do Estado em aplicar as leis e garantir a segurança da população (O'Donnell, 1993; Adorno, 1998a, p. 235).

Recentes análises têm, entretanto, argumentado que, se a concentração da renda permanece a mesma de duas ou três décadas atrás, como explicar então a influência da desigualdade social sobre a violência? Tratase evidentemente de matéria controvertida. Seja o que for, a desigualdade social não é socialmente vivida e experimentada como era há duas ou três décadas. Ampliaram-se os padrões de consumo e de acesso a bens duráveis, mesmo entre os segmentos urbanos mais pauperizados. Não é raro que estudantes de ciências sociais, ao visitarem habitações populares, surpreendam-se com os equipamentos eletrônicos domésticos, inclusive computadores. Decerto melhorou o acesso dos segmentos mais pobres ao conforto proporcionado pelo progresso tecnológico. No entanto permanecem acentuadas restrições de direitos e de acesso às instituições promotoras do bem-estar e da cidadania. Por exemplo, aumentou consideravelmente, no início deste século, a proporção de trabalhadores que jamais tiveram contrato de trabalho formal assinado. A maior parte deles não recebe bonificação de natal (o chamado $13^{\circ}$ salário), algo em torno de 53\%; é elevada também a proporção daqueles que não percebem férias remuneradas (54\%). Entre 1996 e o ano passado, o percentual de brasileiros com 
16 anos ou mais que se declararam sem ocupação e em busca de emprego saltou de $4 \%$ para $11 \%$ (Folha de São Paulo, 24/03/02). Se alguns direitos foram conquistados, outros foram perdidos e outros ainda não alcançaram a maioria dos trabalhadores, como a cidadania eletrônica e informativa. $\mathrm{O}$ acesso à internet ainda é restrito, como também permanecem restritos os números indicativos do mercado consumidor de livros, de revistas e de jornais.

Registros de mortes violentas revelam maior incidência nos bairros que compõem a periferia urbana onde são precárias as condições sociais de existência coletiva e onde a qualidade de vida é acentuadamente degradada. Há fortes evidências de que o risco de ser vítima de homicídio é significativamente superior entre aqueles que habitam áreas, regiões ou bairros com déficits sociais e de infra-estrutura urbana, como aliás sugerem os mapas de risco elaborados para diferentes capitais brasileiras (CEDEC, 1996 e 1997; vide também Dillon Soares, 2000; Cano, 1998; Cano e Santos, 2001; Cardia e Schiffer, 2000). Por exemplo, no Município de São Paulo, no ano de 1995, enquanto a taxa de homicídios era de 42,59 ocorrências por 100.000 habitantes, alguns bairros da periferia urbana acusavam taxas muito mais elevadas: Jardim Ângela, 111,52 ocorrências/cem mil; Grajaú, 101,68 ocorrências/cem mil; Parelheiros, 96,80 ocorrências/ cem mil. Trata-se de bairros onde é precária a infra-estrutura urbana, onde são elevadas as taxas de mortalidade infantil, onde a ocupação do solo é irregular e, quase sempre, ilegal e onde é flagrante a ausência de instituições públicas encarregadas de promover o bem-estar - sobretudo acesso a lazer para crianças e adolescentes - como também de instituições encarregadas de aplicar lei e ordem. A presença destas agências é, não raro, associada aos fatos que denotam violência desmedida, repressão incontida e descaso de atendimento nos postos policiais. Em compensação, em um bairro como Perdizes, onde habitam preferencialmente cidadãos proce- 


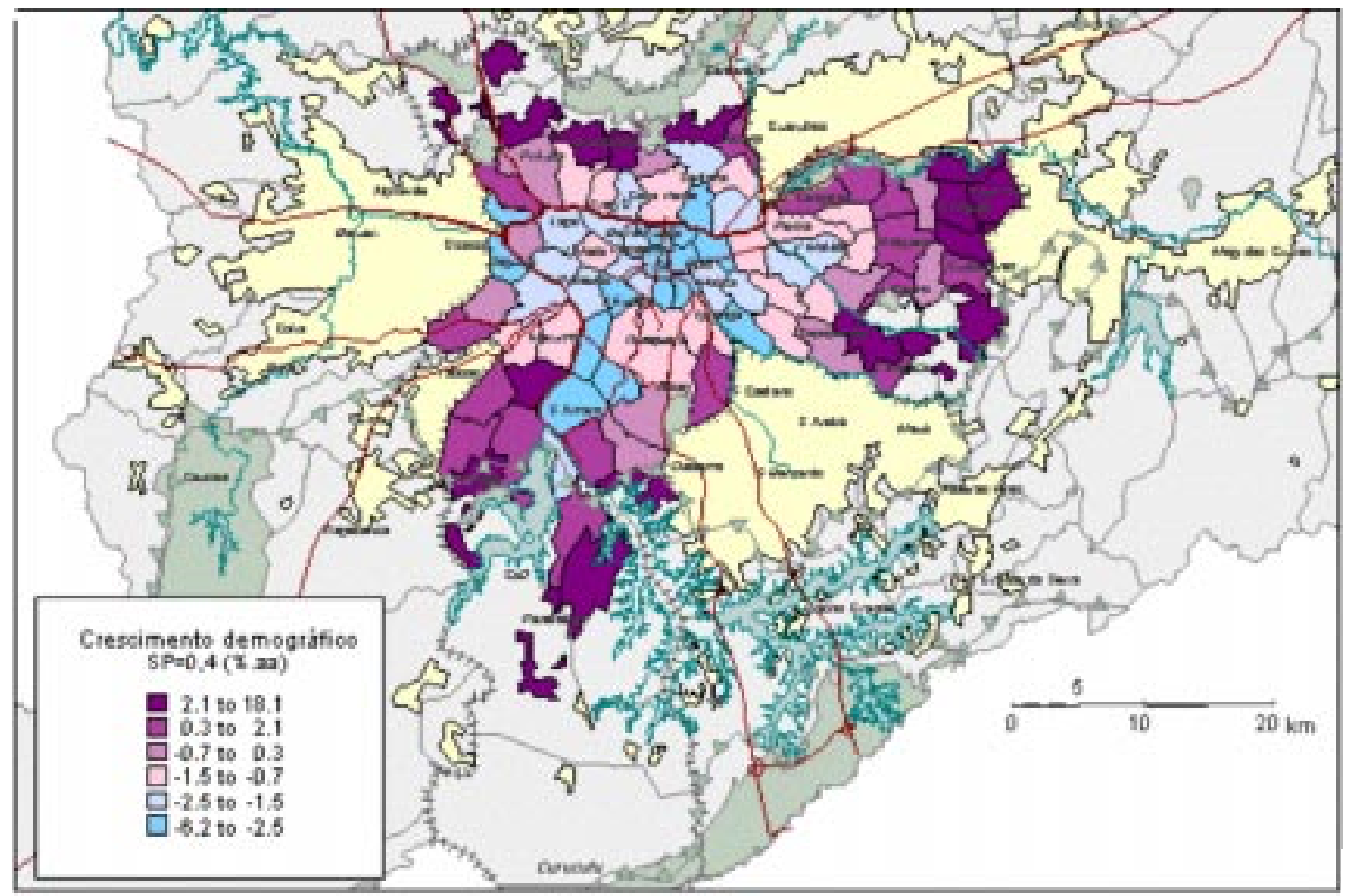

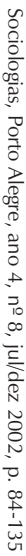

Fonte: Infurb-FAU/USP.

Gráfico 6. (mapa) 
dentes das classes médias profissionalizadas, a taxa é de 2,65 homicídios/ cem mil habitantes (CEDEC, 1996). Nesse bairro, predominam adequadas condições de vida, circulação e acesso ao comércio e ao lazer. Como se vê, é acentuada a distribuição desigual do direito à vida.

Estudo que vem sendo realizado no Núcleo de Estudos da Violência (Cárdia e Schiffer, 2000) procura estabelecer relações entre a distribuição espacial da violência e a distribuição espacial das condições de vida e de infra-estrutura urbana. O estudo revela que uma série de indicadores de má distribuição de recursos e de equipamentos urbanos encontra-se concentrado fora da chamada zona expandida do centro - uma área onde as condições e infra-estrutura urbana são mais favoráveis. É, por conseguinte, nos chamados bairros que compõem a periferia do Município de São Paulo, que ambas as formas de distribuição espacial - maior concentração da violência e maior concentração da desigualdade - são visíveis. Nesta área, é maior a concentração populacional, o crescimento demográfico, a proporção de crianças e adolescentes, o congestionamento domiciliar (isto é, a proporção de pessoas vivendo por cômodo da habitação). Também é a região de menor oferta de empregos, de menor oferta de leitos hospitalares e de menor oferta de espaços e agências de promoção de lazer. É também nelas que se concentram as taxas mais elevadas de homicídio. Abaixo, seguem ilustrações deste fenômeno. Os mapas têm por referência o Município de São Paulo.

Tendências idênticas podem ser observadas quando se examinam o congestionamento habitacional e a distribuição espacial dos homicídios:

Somos levados a perguntar: é possível falar em respeito aos direitos humanos numa sociedade na qual vigem extremas desigualdades sociais? Vale dizer, como não falar em violência se sequer os direitos sociais fundamentais - o direito ao trabalho, à educação, à saúde, ou seja, aqueles para $63,4 \%$ ). Observou igualmente que os $10 \%$ mais pobres revelaram um aumento de renda em redor de $30 \%$. De acordo com o economista Paulo Levy, coordenador da pesquisa, a estabilização dos preços, ao lado do crescimento econômico pós-Plano Real e o aumento médio dos salários respondem pelas principais causas na mudança do perfil da distribuição da renda no Brasil. 


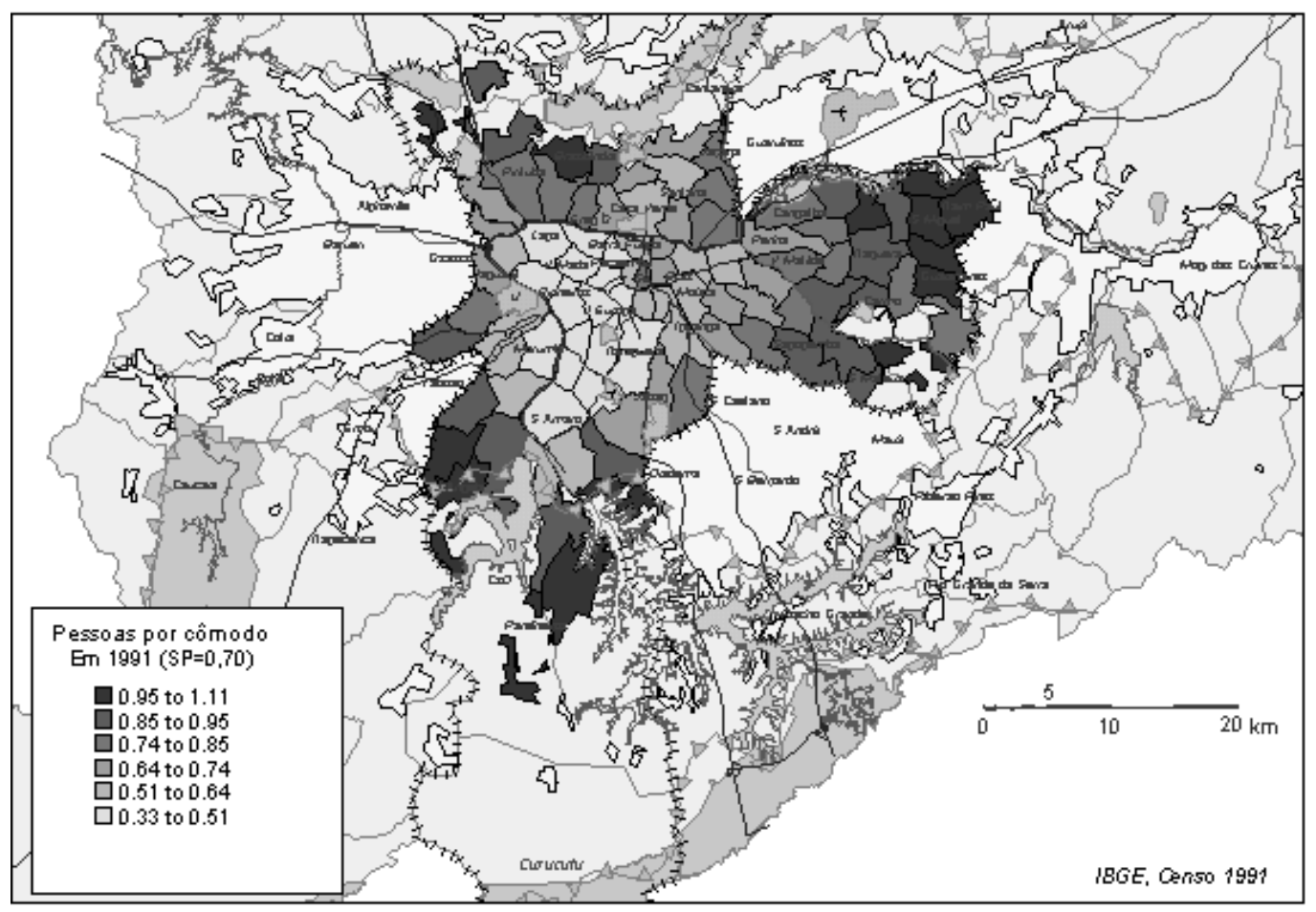

Fonte: Infurb-FAU/USP

Gráfico 7. (mapa) 

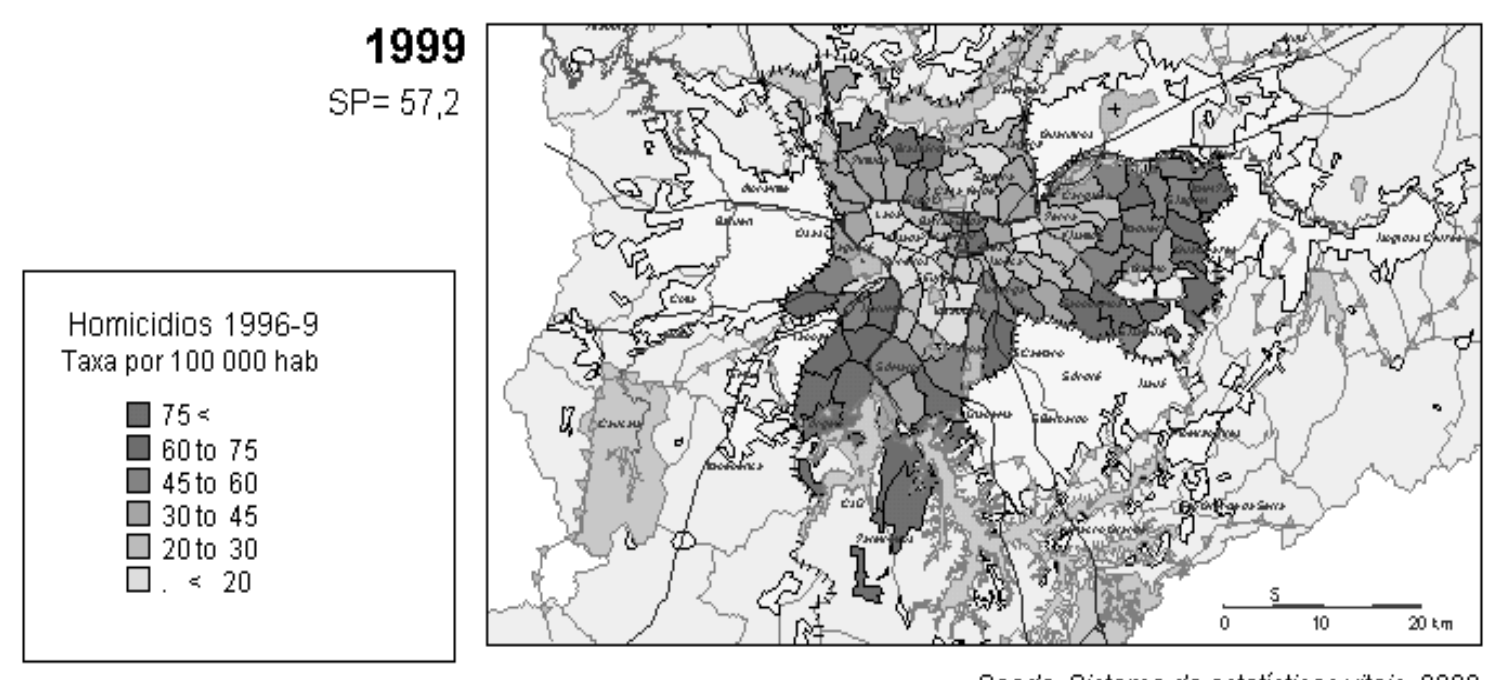

Seade, Sistema de estatisticas vitais, 2000

Gráfico 8. (mapa) 
direitos que recobrem a dignidade da pessoa humana - não estão universalizados, isto é, assegurados para todos os cidadãos? ${ }^{27}$ De fato, tudo indica que os problemas postos pela pobreza, pela desigualdade social e pela exclusão social, entre os quais a sistemática e cotidiana violação dos direitos fundamentais da pessoa humana, não resultam, ao menos exclusivamente, de um modelo de desenvolvimento econômico-social incompleto. A pobreza e suas conseqüências, diretas e indiretas, não constituem resíduos patológicos de um processo inexorável de crescimento econômico cujo ciclo de evolução e desenvolvimento, uma vez concluído, conduziria inevitavelmente a superá-los e a decretar sua definitiva extinção em nossa sociedade. Ao contrário, tudo converge para sugerir que, antes de um problema de natureza econômica relacionada quer a perturbações momentâneas do mercado e do processo de produção industrial, quer a estágios incompletos do desenvolvimento, a pobreza e as desigualdades sociais que lhe subjazem são da ordem da justiça social.

Sua superação requer o reconhecimento de direitos, vale dizer, de medidas de eqüidade que traduzam diferenças em cidadania universal e que assegurem o reconhecimento de um espaço - o espaço público - como locus privilegiado de realização do bem comum. Diz respeito à construção de um repertório de normas, princípios gerais, a partir dos quais se dá a intolerância e a resistência moral dos cidadãos para com a violação de seus direitos fundamentais, entre os quais o mais importante desses direitos - o direito à vida. Sob esta perspectiva, a vida torna-se o mais precioso bem, sob o qual se encontram edificados todos os demais direitos à liberdade, à igualdade, à propriedade e à segurança. Ao mesmo tempo, tudo isso diz respeito também ao reconhecimento de critérios universais e legítimos, socialmente pactuados e compartilhados, de julgamento dos litígios e das contendas sociais.

É nesta medida que se podem estabelecer as conexões entre justiça social e justiça penal, entre a redução do hiato entre direitos políticos e direitos sociais, por um lado, e a preservação dos direitos fundamentais da 
Sociologias, Porto Alegre, ano 4, no 8, jul/dez 2002, p. 84-135

pessoa humana, por outro, enquanto exigência não apenas de pacificação social como também de cidadania democrática. Em uma sociedade como a brasileira, na qual não se universalizou o modelo contratual de organização societária, e não prevalece o reconhecimento do outro como sujeito de direitos, no qual muitos se encontram à mercê de poucos, em que vige, sem interditos, acentuada assimetria no acesso aos recursos, bem como a sua distribuição, e a vida de muitos não tem o mesmo valor e significado da vida de alguns, somente pode ser instituída a "guerra de todos contra todos" como modo de funcionamento regular e normal. Daí que a violação de direitos humanos não seja menos escandalosa que a desigualdade social e o espectro de pobreza.

\section{Referências}

ADORNO, S. Os aprendizes do poder. Rio de Janeiro: Paz e Terra, 1988.

ADORNO, S. Crime, justiça penal e igualdade jurídica: os crimes que se contam no tribunal do júri. Revista USP 21, São Paulo, mar/mai, 1994, p. 133-51.

ADORNO, S. Discriminação racial e justiça criminal. Novos Estudos: Cebrap. São Paulo: Cebrap 43, nov, 1995, p. 45-63.

ADORNO, S. O gerenciamento público da violência urbana: a justiça em ação. In: Pinheiro, P.S. (org). São Paulo sem medo: um diagnóstico da violência urbana. Rio de Janeiro: Garamond, 1997, p. 227-246.

ADORNO, S. Conflitualidade e violência: reflexões sobre a anomia na contemporaneidade. Tempo Social, Revista de Sociologia da USP. São Paulo, 10(1), 1998, p. 19-47.

ADORNO, S. e BORDINI, E. Reincidência e reincidentes penitenciários em São Paulo, 1974-1985. Revista Brasileira de Ciências Sociais. São Paulo: ANPOCS 9(3), fev, 1989, p. 70-94. 
ADORNO, S. e CARDIA, N. Dilemas do controle democrático da violência: execuções sumárias e grupos de extermínio. São Paulo (Brasil), 1980-1989. In: Santos, J.V.T. dos (Org). Violências em tempo de globalização. São Paulo: Hucitec, 1999, p. 66-90.

ADORNO, S. e PEDROSO, J. Políticas de controlo e repressão ao tráfico internacional de drogas: Estudo comparativo de Brasil e Portugal (1980-1990). In: Pureza, J.M. e Ferreira, A C. (Orgs). A teia global: movimentos sociais e instituições. Dir.: Boaventura de Sousa Santos. Porto: Afrontamento, cap. 7, 2001, p. 219-253.

ADORNO, S.; LIMA, R. S. e BORDINI, E. O jovem e a criminalidade urbana em São Paulo. Relatório de Pesquisa. Brasília - DF: Ministério da Justiça, Secretaria Nacional de Direitos Humanos, 1999.

ARLACHI, P. De la 'mafia' au marché libre: drogue et criminalité dans la province de Vérone. In: Ehrenberg, A. e Mignon, P. (Orgs). (1992). Drogues, politique et société. Paris: Éditions Descartes, 1992.

ASSIS, S. Crescer sem violência: um desafio para educadores. Brasília: Ser: Superando a violência, 1997.

BARCELLOS, C. Rota 66. A história da polícia que mata. 19a. ed. Rio de Janeiro: Globo, 1993.

BEATO. Determinantes da criminalidade em Minas Gerais. São Paulo: Revista Brasileira de Ciências Sociais13(37), jun, 1998, p. 74-87.

BEATO e REIS. Desigualdade, desenvolvimento sócio-econômico e crime. In: Henriques, R. (Org). Desigualdade e pobreza no Brasil. Rio de Janeiro: IPEA, 1999, p. 385-404.

BOBBIO, N. A era dos direitos. Rio de Janeiro: Campus, 1992.

BOX, S. Recession, crime and punishment. London: Macmillan Press, 1987.

BRANT, V.C. O trabalho encarcerado. Rio de Janeiro: Forense, 1994.

CALDEIRA, T.P. do R. Cidade de muros: crime, segregação e cidadania em São Paulo. São Paulo: EDUSP/Paralelo 34, 2000. 
Sociologias, Porto Alegre, ano 4, no 8, jul/dez 2002, p. 84-135

CANO, I. Uso da força letal pela Polícia do Rio de Janeiro: os fatos e o debate. Archè, ano 7, n. 19, 1998, p. 201-229.

CANO, I. e SANTOS, W. Violência letal, renda e desigualdade social no Brasil. Rio de Janeiro: 7letras, 2001.

CARDIA, N. Direitos humanos: ausência de cidadania e exclusão moral. Princípios de Justiça e Paz. São Paulo: Arquidiocese de São Paulo/Comissão Justiça e Paz, 1994.

CARDIA, N. Pesquisa sobre atitudes, normas culturais e valores em relação à violência em dez capitais brasileiras. Relatório de pesquisa. Brasília - DF, Ministério da Justiça, Secretaria Nacional de Direitos Humanos, 1999.

CARDIA, N. Exposure to violence: what impact this has on attitudes to violence and on social capital. Paper prepared to Seminary on Violence, Centre de Recherches et d'Analyses Sociologiques, Maison des Sciences de I'Homme, Paris, dez, 2001.

CASSESSE, A. Los derechos humanos en el mundo contemporâneo. Barcelona: Ariel, 1991.

CASTRO, M. M. Assassinatos de crianças e adolescentes no Estado de São Paulo. Revista Crítica de Ciências Sociais. Coimbra: Centro de Estudos Sociais/CES 36, fev, 1993, p. 81-102.

CECCHETO, F. Galeras funk cariocas: entre o lúdico e o violento. In: Vianna, H. Galeras cariocas. Rio de Janeiro: Editora da UFRJ, 1997.

CHEVIGNY, P. Police deadly force as social control: Jamaica, Argentina and Brazil. Criminal Law Forum. Princeton, N. J., 1(3), spring, 1990, p. 389-425.

COELHO, E.C. A criminalidade urbana violenta. Dados - Revista de Ciências Sociais. Rio de Janeiro: luperj, 31(2), 1988, p. 145-83.

DILLON SOARES, G. A Homicídios no Brasil: vários factóides em busca de uma teoria. Relatório parcial de pesquisa. Covariatas macroestruturais do homicídio no Brasil. Apresentado em "Meeting of Latin American Studies Association LASA", Miami, March 16-18, 2000. 
DIÓGENES, G. Cartografias da cultura e da violência: gangues, galeras e movimento hip hop. São Paulo: AnnaBlume, 1998.

DONZIGER, ed. The real war on crime. The Raport of the National Criminal Justice Commssion. New York: Harpers Collins Publishers, Inc., 1996.

ELIAS, N. Violence and civilization: the State monopoly of physical violence and its infringement. In: Keane, J. (ed.), Civil society and the State. London: Verso, 1987, p. 177-98.

FAUSTO, B. Crime e cotidiano: a criminalidade em São Paulo (1880-1924). São Paulo: Brasiliense, 1984.

FOUCAULT, M. e FARGE, A Les désodres des familles. Lettres de Cachet des Archives de la Bastille. Paris: Gallimard, 1992.

FRANCO, M. S. de C. Homens livres na ordem escravocrata. 2.ed. São Paulo: Ática, 1976.

Fundação Instituto Brasileiro de Geografia e Estatística, Departamento de Estatísticas e de Indicadores Sociais. Participação político-social no Brasil, 1988. Brasil e grandes regiões. Rio de Janeiro: IBGE, 1990.

Fundação João Pinheiro, Centro de Estudos Políticos e Sociais - CEPS, Sistema Estadual de Planejamento. Indicadores sociais de criminalidade. Paixão, A.L., coord. Belo Horizonte, mimeo. 168p, 1986.

GARLAND, D. The culture of control: crime and social order in contemporary society. Chicago: University of Chicago Press, 2001.

GURR, T. R. Crime trends in modern democracies since 1945. International Annals of Criminology, 16, 1989.

IZUMINO, W.P. Justiça e violência contra a mulher. O papel do sistema judiciário na solução dos conflitos de gênero. São Paulo: FAPESP/AnnaBlume, 1998.

LAMOUNIER, B. Brazil: inequality against democracy. In: Diamond, L et al. (eds). Democracy in developing countries: Latin America. London: Lynne Rienner Publishers, 1999. 
Sociologias, Porto Alegre, ano 4, no 8, jul/dez 2002, p. 84-135

MAGUIRE. Crime statistics, patterns and trends: changing perceptions and their implications. In: Maguire et al. (Eds). The Oxford handbook of criminology. Oxford: Clarendon Press, 1997.

MARTINS, J. de S. Crise do Brasil agrário. São Paulo: Arte e Ciência, 1971.

MELLO JORGE, M.H. P. Mortalidade por causas violentas no município de São Paulo. Mortes intencionais. Revista de Saúde Pública 15. São Paulo: Faculdade de Saúde Pública, 1981, p. 165-193.

MELLO JORGE, M.H.P. Mortalidade por causas violentas no Município de São Paulo. A situação em 1980. Revista de Saúde Pública 16. São Paulo: Faculdade de Saúde Pública, 1982, p. 19-41.

MELLO JORGE, M.H.P. Mortes violentas em menores de 15 anos no Brasil. Boletín de la Oficina Sanitaria Panamericana. Col. 100, no. 6, junho, 1986.

MELLO JORGE, M.H. P. Os adolescentes e jovens como vítimas da violência fatal em São Paulo. In: Pinheiro, P.S. (Org). São Paulo sem medo: um diagnóstico da violência urbana. Rio de Janeiro: Garamond, 1997, p. 97-120.

MESQUITA NETO, P. Crime, violência e incerteza política no Brasil. In: A violência do cotidiano. Cadernos Adenauer. São Paulo: Fundação Kinrad Adenauer, 2001, p. 9-41.

MORIS, T. Crime and criminal justice since 1945. London: Institute of Contemporary British History/Basil Blackwell, 1989.

MOTT, L. Homossexuais: as vítimas principais da violência. In: Velho, G. e Alvito, M. (Orgs). Cidadania e violência. Rio de Janeiro: Editora da UFRJ e FGV-RJ, 1996.

Núcleo de Estudos da Violência, Universidade de São Paulo - NEVUSP. Os direitos humanos no Brasil. São Paulo: NEV-USP, 1993.

O'DONNELL, G. Reflexões sobre os Estados burocrático-autoritários. São Paulo: Vértice, 1987.

PAIXÃO, A L. Crimes e criminosos em Belo Horizonte, 1932-1978. In: Pinheiro, 
P.S. (Org). Crime, violência e poder. São Paulo: Brasiliense, 1983.

PÉCAUT, D. Trafic de drogue et violence en Colombie. In: Cultures \& Conflits. Mafia, Drogue et Politique. Paris: Centre d'Études des Conflits; L'Harmattan, 3, automne, 1991, p. 141-56.

PÉCAUT, D. Violence et politique: quatre éléments de réflexion à propos de la Colombie. Cultures \& Conflits. Disparitions. Paris: Centre d'Études des Conflits; L'Harmattan, 1994, p.13-14; 155-66.

PEZZIN, L. Criminalidade urbana e crise econômica. São Paulo: IPE/USP, 1986.

PINHEIRO, P.S. Violência do Estado e classes populares. Dados - Revista de Ciências Sociais. Rio de Janeiro: luperj, 22(3), 1979, p. 5-24.

PINHEIRO, P.S. Autoritarismo e transição. Revista USP 9, São Paulo, 1991, mar/ mai, p. 45-56.

PINHEIRO, P.S. et al. Violência fatal: conflitos policiais em São Paulo (81-89). Revista USP 9, São Paulo, 1991, mar/mai, p. 95-112.

PINHEIRO, P.S; ADORNO, S.; CARDIA, N. et al. Continuidade autoritária e construção da democracia. Rel. de pesquisa. São Paulo: NEV/USP, v. 4, 1999.

PORTO, M. S G. Violência e segurança: a morte como poder? In: Oliveira, D. D. e outros (Orgs). Violência policial: tolerância zero? Goiânia: Editora da UFG, 2001, p. 29-51.

RIBEIRO, C. A C. Cor e criminalidade: estudo e análise da Justiça no Rio de Janeiro. Rio de Janeiro: Editora da UFRJ, 1995.

ROBERT et al. Les comptes du crime. Paris: L'Harmattan, 1994.

SANTOS, W.G. dos. Razões da desordem. Rio de Janeiro: Rocco, 1993.

SAPORI, L. F. e WANDERLEY, C. B. A relação entre desemprego e violência na sociedade brasileira: entre o mito e a realidade. In: A violência do cotidiano. Cadernos Adenauer. São Paulo: Fundação Kinrad Adenauer, 2001, p. 42-73. 
Sociologias, Porto Alegre, ano 4, no 8, jul/dez 2002, p. 84-135

SCHIRAY, M. Essai sur l'illégalité en économie: I'économie de la drogue. Sciences Sociales et Santé, VII(3), 1989, p. 5-25.

SCHIRAY, M. La Grand-Bretagne. Approches nationales des marchés européens. In: Schiray; M. (org). Penser la drogue, penser les drogues. II - Les marchés interdits de la drogue. Paris: Editions Descartes, 1992.

SCHIRAY, M. Les filières-stupéfiants: trois niveaux, cinq logiques. Futuribles. Paris, 185, mars, 1994, p. 23-41.

SOARES, L.E. et al. Violência e política no Rio de Janeiro. Rio de Janeiro: RelumeDumará, 1996.

SOARES, L.E. Meu casaco de general: $\mathbf{5 0 0}$ dias no front da segurança do Rio de Janeiro. São Paulo: Cia. das Letras, 2000.

SPAGNOL, A S. O desejo marginal. São Paulo: Arte e Ciência, 2001.

SPÓSITO, M. P. Um breve balanço da pesquisa sobre violência escolar no Brasil. Educação e Pesquisa. Revista da Faculdade de Educação da USP, 27(1), 2001, p. 87-103.

TAVARES DOS SANTOS, J. V. A violência na escola: conflitualidade social e ações civilizatórias. Educação e Pesquisa. Revista da Faculdade de Educação da USP, 27(1), 2001, p. 105-122.

VARGAS, J. Crimes sexuais e sistema de justiça. São Paulo: INCRIM, 2000.

VIANA, H. Galeras cariocas. Rio de Janeiro: Editora da UFRJ, 1996.

VIÑAS, A R. El abuso de los derechos fundamentales. Barcelona: Península, 1983.

WEBER, M. A política como vocação. In: Ciência e política: duas vocações. São Paulo: Cultrix, 1970.

WEBER, M. Classe, status e partido. In: Ensaios de sociologia. Rio de Janeiro: Zahar, 1971.

WRIGHT, K. The great american crime myth. New York: Praeger, 1987. 
YAZABI e FLORES, O. Mortalidade infanto-juvenil. In: O jovem na Grande São Paulo. São Paulo: Fundação Seade, 1988.

ZALUAR, A. Condomínio do diabo. Rio de Janeiro: Revan e UFRJ, 1994.

ZALUAR, A Para não dizer que não falei de samba. Os enigmas da violência no Brasil. In: Schwarcz, L. (Org). História da vida privada no Brasil. São Paulo: Cia. das Letras, v.4, 1998.

ZALUAR, A Violência e crime. In: Miceli, S. (Org). O que ler na ciência social brasileira (1970-1995). São Paulo: Sumaré; ANPOCS, 1999, p. 13-107.

ZALUAR, A. e MONTEIRO, M. Determinantes socioeconômicos da mortalidade de jovens no município do Rio de Janeiro. Paper apresentado na XXI Reunião Anual da ANPOCS, Caxambu, MG, 1998.

\section{Resumo}

Este texto aborda as relações entre violência e exclusão socioeconômica a partir de um caso determinado: o caso brasileiro. Traça um quadro das características e tendências mais recentes da violência. Examina três causas que comparecem ao debate público: mudanças nos padrões de violência e criminalidade, crise no sistema de justiça criminal, e desigualdade social e segregação urbana. Em particular, quanto a este último aspecto, procura, de modo geral, comentar as principais "teses" que sustentam ou contestam a chamada violência estrutural.

Palavras-chave: violência, direitos humanos, justiça, democracia, direitos sociais. 